\title{
Marszałkowie świeccy Trybunału Głównego Wielkiego Księstwa Litewskiego w latach 1633-1648
}

I. Podstawą rozważań w niniejszym tekście są - powstałe pod redakcją Andrzeja Rachuby - spisy deputatów Trybunału Głównego Wielkiego Księstwa Litewskiego ${ }^{1}$ oraz spisy litewskich urzędników ziemskich i grodzkich, które jak dotąd ukazały się dla województw: smoleńskiego ${ }^{2}$, wileńskiego ${ }^{3}$ oraz trockiego ${ }^{4}$, ponadto spisy urzędników inflanckich ${ }^{5}$ oraz urzędników centralnych Wielkiego Księstwa ${ }^{6}$. Pozwalają one na dokładne prześledzenie karier urzędniczych nie tylko marszałków deputackich Trybunału, ale także deputatów, którymi często zostawali urzędnicy różnego szczebla. Pomimo błędów, wiele cennych informacji na temat poszczególnych przedstawicieli szlachty litewskiej można również znaleźć w herbarzach i zestawieniach Józefa Wolf$\mathrm{fa}^{7}$. Także pamiętniki litewskie pochodzące $\mathrm{z}$ omawianej epoki pozwalają na pogłębienie wiedzy o funkcji marszałka trybunalskiego, dostarczając konkretnych przykładów ukazujących jego wpływ na funkcjonowanie tego sądu. Dla

${ }^{1}$ Deputaci Trybunału Głównego Wielkiego Księstwa Litewskiego - spis (1582-1696), red. A. Rachuba, oprac. H. Lulewicz i A. Rachuba, Warszawa 2007 (dalej: Deputaci).

${ }^{2}$ Urzędnicy Wielkiego Księstwa Litewskiego. Spisy, t. IV. Ziemia smoleńska i województwo smoleńskie XIV-XVIII wiek, red. A. Rachuba, oprac. H. Lulewicz, A. Rachuba, P.R. Romaniuk, Warszawa 2003 (dalej: Urzędnicy smoleńscy).

${ }^{3}$ Urzędnicy Wielkiego Księstwa Litewskiego. Spisy, t. I. Województwo wileńskie XIV-XVIII wiek, red. A. Rachuba, oprac. H. Lulewicz, A. Rachuba, P.R. Romaniuk, Warszawa 2004 (dalej: Urzędnicy wileńscy).

${ }^{4}$ Urzędnicy Wielkiego Księstwa Litewskiego. Spisy, t. II. Województwo trockie XIV-XVIII wiek, red. A. Rachuba, oprac. H. Lulewicz, A. Rachuba, P. R. Romaniuk, A. Haratym, Warszawa 2009 (dalej: Urzędnicy troccy).

${ }^{5}$ Urzędnicy dawnej Rzeczypospolitej XII-XVIII wieku. Spisy, t. IX. Urzędnicy inflanccy XIV-XVIII wieku, oprac. K. Mikulski i A. Rachuba, Kórnik 1994 (dalej: Urzędnicy inflanccy).

${ }^{6}$ Urzędnicy dawnej Rzeczypospolitej XII-XVIII wieku. Spisy, t. XI. Urzędnicy centralni i dostojnicy Wielkiego Księstwa Litewskiego XIV-XVIII wieku, oprac. H. Lulewicz i A. Rachuba, Kórnik 1994.

${ }^{7}$ Ważniejsze prace: Senatorowie i dygnitarze Wielkiego Księstwa Litewskiego (1386-1795), Kraków 1885; Kniaziowie litewsko-ruscy od końca XIV wieku, Kraków 1895; Pacowie. Materyjały historyczno-genealogiczne, Petersburg 1885. 
panowania Władysława IV Wazy interesujący pod tym względem jest pamiętnik kanclerza litewskiego Albrychta Stanisława Radziwiłła ${ }^{8}$.

Podobnie jak izba poselska miała swojego marszałka, tak obradom Trybunału Głównego przewodniczyła osoba nazywana marszałkiem lub zamiennie, w XVII wieku, dyrektorem Trybunału. Procedura jego wyboru była podobna jak przy wyborze marszałka poselskiego. Był on wybierany w dniu inauguracji sądów spośród wszystkich deputatów ${ }^{9}$. W teorii zatem marszałkiem trybunalskim mógł zostać każdy zgodnie z prawem wybrany deputat, a więc taki, który przeszedł pomyślnie procedurę rugów. W praktyce dyrektorem zostawał zazwyczaj deputat piastujący godność senatorską lub też osoba z rodziny magnackiej będąca najczęściej na początku swojej kariery urzędniczej. Jeśli na sejmikach deputackich został wybrany więcej niż jeden senator, wtedy zdarzało się, że każdy był dyrektorem Trybunału, a marszałkiem inauguracyjnym zostawał ten, który pełnił wyższy urząd senatorski. Nie stanowiło to jednak reguły. Na przykład w 1643 roku deputatami byli wojewoda witebski Krzysztof Kiszka, kasztelan połocki Jan Anzelm Wilczek i kasztelan witebski Ostafi (Eustachy) Kurcz, ale żaden nie został marszałkiem ${ }^{10}$.

W roku 1642 marszałkami byli: wojewoda nowogródzki Aleksander Słuszka oraz podskarbi nadworny litewski Antoni Jan Tyszkiewicz ${ }^{11}$. Pierwszy przewodniczył obradom podczas kadencji wileńskiej i nowogródzkiej, drugi natomiast był marszałkiem tylko kadencji wileńskiej. Taka sama sytuacja miała miejsce również w 1647 roku, kiedy dyrektorami Sądu Głównego (jak bywał nazywany Trybunał) zostali wojewoda wileński Krzysztof Chodkiewicz ${ }^{12}$ i - po raz trzeci - Antoni Jan Tyszkiewicz, będący już wtedy marszałkiem nadwornym Wielkiego Księstwa, którym został w 1645 roku $^{13}$. Wcześniej był marszałkiem kadencji nowogródzkiej w 1638 roku $^{14}$. Z kolei dla Chodkiewicza było to już czwarte kierowanie obradami Sądu Głównego. Był jedynym marszałkiem w 1643 roku $^{15}$, a ponadto był jeszcze wybierany na tę funkcję trzykrotnie: w 1635, $1639 \mathrm{i}$ w 1651 roku$^{16}$. Tak wiele następujących po sobie nominacji może świadczyć nie tylko o sprawnym przewodniczeniu i kierowaniu pracami Trybunału, ale też o chęci wpływania na zapadające wyroki.

${ }^{8}$ A.S. Radziwiłł, Pamiętnik o dziejach w Polsce, oprac. A. Przyboś i R. Żelewski, t. 1-3, Warszawa 1980.

${ }^{9}$ Deputaci, s. 33.

${ }^{10}$ Ibidem, s. 242, 244. Krzysztof Kiszka był tylko marszałkiem koła duchownego.

${ }^{11}$ Ibidem, s. 237.

${ }^{12}$ Urzędnicy wileńscy, $\mathrm{nr} 1114$.

${ }^{13}$ Urzędnicy centralni, $\mathrm{nr} 448$.

${ }^{14}$ Deputaci, s. 225.

${ }^{15}$ Ibidem, s. 241.

${ }^{16}$ R. Mienicki, Chodkiewicz Krzysztof, Polski Słownik Biograficzny (dalej: PSB), t. 3, 1937, s. 370 . 
Oprócz wyżej wymienionych senatorów, dyrektorami Sądu Głównego w latach 1633-1648 byli jeszcze czterej inni. Pierwszym był kasztelan trocki Mikołaj Kiszka, jedyny marszałek obu kadencji w 1637 roku $^{17}$. W następnym roku dyrektorem Trybunału został jego młodszy brat Krzysztof ${ }^{18}$, będący wtedy wojewodą mścisławskim ${ }^{19}$. W 1644 roku godność marszałka pełnił w Wilnie i Nowogródku kasztelan trocki Andrzej Stanisław Sapieha ${ }^{20}$. Ostatnim z grupy marszałków-senatorów był w 1648 roku starosta żmudzki i hetman polny litewski Janusz Radziwiłł, ale tylko w Wilnie, kadencja nowogródzka bowiem z powodu śmierci Władysława IV nie odbyła się, a sam Trybunał jeszcze w trakcie trwania sesji wileńskiej przekształcił się w konwokację i uchwalił kaptur Wielkiego Księstwa ${ }^{21}$.

Nie zawsze marszałek mógł uczestniczyć we wszystkich zebraniach deputatów. Dotyczyło to szczególnie marszałków-senatorów, którzy - choćby z racji pełnienia swoich urzędów - mieli wiele innych obowiązków. Czasami dochodziły także inne przyczyny, niezależne już od samego szlachcica, takie jak: choroba, śmierć bliskiego członka rodziny, czy po prostu niedojechanie na czas $\mathrm{z}$ powodu złego stanu dróg. W takich przypadkach wybierano marszałków-zastępców ${ }^{22}$, którzy oczywiście posiadali te same kompetencje i obowiązki co marszałek wybrany w dniu inauguracji sądów, choć już niekoniecznie cieszyli się tym samym autorytetem, co wpływać mogło na pracę Trybunału. Takie sytuacje miały miejsce bardzo często. W czasie panowania Władysława IV tylko w 1637 i 1643 roku nie było marszałków-zastępców. W latach 1633, 1634, 1635, 1636, 1638, 1639, 1642, 1646 i 1648 Trybunałowi Głównemu przewodniczyło co najmniej trzech dyrektorów. Najwięcej, bo aż pięciu marszałków miały Trybunały w 1638 i 1642 roku. Czterech marszałków było wybranych w 1633 roku, natomiast w pozostałych - nie wymienionych - latach na czele Sądu Głównego stały po dwie osoby. Łącznie dla 16 Trybunałów litewskich, które zebrały się w czasie panowania Władysława IV otrzymujemy liczbę 45 marszałków, którymi było 37 różnych osób.

Pod względem urzędów zajmowanych w momencie wyboru na marszałka prym wiedli podkomorzowie. Za panowania Władysław IV pojawili się oni w roli dyrektora Trybunału Głównego aż dziewięć razy, głównie - jako marszałkowie wybrani tylko na jedną kadencję. Często marszałkami zostawali sędziowie ziemscy i grodzcy, podsędkowie oraz pisarze ziemscy i grodzcy. W 1635 roku marszałkami w zastępstwie Krzysztofa Chodkiewicza byli:

\footnotetext{
${ }^{17}$ Deputaci, s. 221.

${ }^{18}$ S. Uruski, Rodzina. Herbarz szlachty polskiej, t. 6, Warszawa 1909 [reprint 1996], s. 360.

${ }^{19}$ Deputaci, s. 224.

${ }^{20}$ Ibidem, s. 244.

${ }^{21}$ Ibidem, s. 257.

${ }^{22}$ Ibidem, s. 35.
} 
podkomorzy upicki Gabriel Białłozor, wybrany w Wilnie, oraz pisarz ziemski połocki Mikołaj Tyszkiewicz „na miejscu marszałka pod koniec sądów w Mińsku"23. W 1641 roku było dwóch marszałków: podkomorzy wileński Jarosław Aleksander Szemiot oraz podsędek lidzki Adam Owsiany ${ }^{24}$. Rok później, oprócz już wcześniej wymienionych Aleksandra Słuszki oraz Antoniego Jana Tyszkiewicza, marszałkami trybunalskim byli jeszcze: podczaszy wiłkomierski Samuel Aleksander Komorowski, sędzia grodzki trocki Michał Konstanty Kolenda oraz pisarz ziemski słonimski Aleksander Kazimierz Wołłowicz $^{25}$. W następnym roku, jako dyrektorzy Sądu Głównego figurowali podkomorzy mścisławski Piotr Kazimierz Wiażewicz, a także Stanisław Albrycht Zenowicz ${ }^{26}$. W 1646 roku w Trybunale nie było ani jednego senatora, zaś marszałków - aż czterech. Byli nimi: podkomorzy brzeski litewski Kazimierz Tyszkiewicz, miecznik mścisławski Mikołaj Walerian Ciechanowiecki, Samuel Stanisław Drucki Sokoliński, będący wtedy podkomorzym smoleńskim oraz podsędek trocki Dymitr Bychowiec ${ }^{27}$. Widać więc, że dyrektorami Trybunału zostawały osoby co najmniej ze średniego szczebla urzędniczego, pochodzące ze znanych i poważanych rodzin szlacheckich w Wielkim Księstwie, choć jeszcze nie wszystkie mogące się poszczycić godnościami senatorskimi. Nie oznacza to jednak, że nie były one już wtedy osobami należącymi do bogatej szlachty czy magnaterii. „Tak jak nie każdy senator był magnatem, tak nie każdy magnat musiał być senatorem"28. O wyborze kandydatów zastępujących marszałka wybranego w dniu inauguracji decydowały w głównej mierze przynależność fakcyjna i wiążące się z tym poparcie wpływowych przywódców oraz popularność wśród szlachty, a mniej - choć formalnie wymagana - znajomość prawa czy umiejętność czytania i pisania „,pismem ruskim”.

II. Z uwagi na interesy polityczno-majątkowe poszczególnych członków elity politycznej Litwy oraz zapewne idący w parze z laską marszałkowską prestiż, funkcja dyrektora Trybunału Głównego była atrakcyjna. Można wymienić wiele wpływowych osobistości, które na Litwie w pierwszej połowie XVII wieku przynajmniej raz piastowały tę godność. Najwybitniejsze zaś - wielokrotnie. Do rekordzistów, oprócz wspomnianego już Krzysztofa Chodkiewicza, należał również jego ojciec Hieronim, a także Lew Sapieha,

\footnotetext{
${ }^{23}$ Ibidem, s. 215.

${ }^{24}$ Ibidem, s. 234.

${ }^{25}$ Ibidem, s. 237-238.

${ }^{26}$ Ibidem, s. 247.

${ }^{27}$ Ibidem, s. 251.
}

${ }^{28}$ Cyt. za: W. Czapliński, J. Długosz, Życie codzienne magnaterii polskiej w XVII wieku, Warszawa 1982, s. 8. Najlepszym przykładem jest chyba Krzysztof II Radziwiłł, który senatorem został dopiero w 1633 roku, a przecież już w latach dwudziestych XVII wieku był jedną z najbardziej wpływowych osób na Litwie. 
Krzysztof Zawisza oraz - w drugiej połowie XVII wieku - starosta lidzki Kazimierz Frąckiewicz Radzimiński ${ }^{29}$.

Istotnym powodem popularności tego stanowiska była bezpośrednia możliwość wpływania na wyroki Trybunału. Można sobie bowiem wyobrazić sytuację, w której marszałek, mający swój interes w wydaniu takiego a nie innego wyroku potrafił, poprzez swój autorytet, odpowiednio „ukierunkować” pozostałych deputatów. Narzędziem pomagającym mu w tym było - na przykład - samowolne ustalanie kolejności rozpatrywania spraw, pomimo wcześniej już ustalonego porządku, zapisanego w rejestrze przez urząd ziemski ${ }^{30}$. Zdarzało się też, że marszałek uniemożliwiał dokonanie wypisu z akt trybunalskich potwierdzającego cesję czy nadanie dóbr ziemskich. Wręcz modelowy przykład takiej sytuacji podał w swoim pamiętniku Albrycht Stanisław Radziwiłł pod datą 7 marca 1644 roku:

Powstał spór między podczaszym litewskim Tryzną ${ }^{31}$ i starostą krzyczewskim Pacem $^{32}$ o dobra w pobliżu Wilna, Rakonciszki i Ławaryszki, w taki sposób. Zmarły podkanclerzy Pac ${ }^{33}$ uzyskał dla swojego syna Mikołaja prawo współposiadania (ius communicationis). Po śmierci męża matka pozwanego dokonała cesji tych wsi na rzecz swego syna w aktach trybunalskich, kiedy marszałkiem trybunału był wojewoda wileński [Krzysztof Chodkiewicz]. Wypisu jednak z akt w żaden sposób nie mogła otrzymać. I w połowie roku, gdy wtedy trybunał wedle prawa był przeniesiony do Mińska, chociaż nieraz prosiła wojewodę o wydanie formuły rezygnacji (formula resignationis), niczego nie zdziałała. Tymczasem umarła matka [...]. Po jej śmierci król wydał przywilej na te dobra podczaszemu litewskiemu. Wojewoda również posyłał do króla, by mu je oddał. Zawiedziony w swej nadziei dopiero wtedy odesłał Pacowi rezygnację matki [...]. Wszyscy senatorowie jednomyślnie przysądzili Pacowi dobra królewskie jako rzeczywiście przed trybunałem przyznane. Wojewoda w swej sentencji wyznał niezbyt ostrożnie, że wprawdzie przyjął rezygnację matki Paca, ale nie chciał jej wydać (gdyż spodziewał się bliskiego jej końca). Zaś po jej śmierci prosił króla o oddanie mu tych dóbr jako niegdyś należących do województwa ${ }^{34}$.

Chodkiewicz próbował więc zataić istnienie dokumentu cesji, licząc, że dobra po podkanclerzym przejdą na własność województwa, czyli de facto wojewody. Całą sytuację dosadnie podsumował Władysław IV:

${ }^{29}$ Deputaci, s. 33.

${ }^{30}$ V. Raudeliūnas, H. Wisner, Z dziejów Trybunatu Głównego Wielkiego Księstwa Litewskiego 1581-1648, „Kwartalnik Historyczny” (dalej: KH), R. 83, z. 4, 1976, s. 952.

${ }^{31}$ Gedeon Michał Tryzna, podczaszy WKsL od 1642, następnie podskarbi od 5 IV 1644 roku (Urzędnicy centralni, nr 1105, 1221; J. Wolff, Senatorowie, s. 292).

${ }^{32}$ Mikołaj Stefan Pac, starosta krzyczewski (idem, Pacowie, s. 173).

${ }^{33}$ Stefan Pac, podkanclerzy WKsL od 26 XI 1635, zmarł 19 XI 1640 roku (Urzędnicy central$n i, \mathrm{nr} 1134)$.

${ }^{34}$ A.S. Radziwiłł, Pamiętnik, t. 2, s. 394-395. 
a wspominając o nieostrożnej mowie wojewody powiedział uśmiechając się do nas, kanclerzy, że wojewoda wyraził się bardziej szczerze aniżeli wstydliwie ${ }^{35}$.

Ponadto marszałkowie trybunalscy rościli sobie prawo do wchodzenia w kompetencje urzędników takich jak wojewodowie, starostowie czy też urzędów niższego szczebla, głównie związanych z działalnością sądów miejskich $^{36}$. Jedna z konstytucji sejmowych uchwalonych już w 1601 roku pod tytułem Władza sędziów, y Marszałka Trybunalskiego wymienia wszystkie bezprawne działania marszałków i deputatów:

Przeto Sędziowie głowni i ich Marszałek, w żaden urząd, onego miejsca gdzie sądy odprawuią, wdawać się nie maią: gospod rozdawać, ustaw rzeczom czynić, myta, albo targowych wybierać, ani sobie żadnych pożytkow, na onym mieyscu gdzie sądy odprawuią przywłaszczać, y wynaydować nie maią, oprocz salarium swego sądowego: ani privata authoritate $\mathrm{w}$ gospodach sądow żadnych odprawować, y więzienia mieć nie maią. Ludzi mieyskich szotow, rzemiesłnikow, przekupniow, y innych, ktorzy między sobą sprawy maią, do swych sądow nie wciągać, zostawuiąc każdego przy iego iurisdykcyi: oprocz wedle konstytucyi Trybunalskiey, sądy sobie należące odprawować będą ${ }^{37}$.

Przy kulejącej wówczas egzekucji prawa należy mieć wątpliwość, czy konstytucja ta była przez wszystkich marszałków respektowana?

Często też marszałkowie pełniący niższe urzędy, w zdecydowanej większości związani przynależnością fakcyjną, ulegali naciskom swoich protektorów. Tak prawdopodobnie było w 1636 roku w przypadku Władysława Monwida Dorohostajskiego, który jako marszałek początkowo nie chciał przyjąć do akt trybunalskich protestacji napisanej przez kanclerza A.S. Radziwiłła, która winą za zerwanie komisji mającej dokonać rewizji Statutu litewskiego obciążała dysydentów ${ }^{38}$. Uczynił tak nie tylko dla tego, że sam był kalwinistą, ale zapewne też ze względu na Krzysztofa Radziwiłła, swojego protektora i przywódcę dysydentów litewskich.

Kolejną przyczyną podnoszącą atrakcyjność stanowiska dyrektora Sądu Głównego była możliwość zaistnienia na niwie publicznej i pokazania się braci szlacheckiej oraz dworowi królewskiemu. Z reguły na sądy Trybunału zjeżdżała się spora liczba szlachty, głównie stron bądź świadków. Wykazanie się, szczególnie przez marszałków będących dopiero na początku swojej kariery urzędniczej, kompetencją oraz znajomością prawa, jak i sprawnym kierowaniem rozprawami, mogło w przyszłości przyczynić się do wzrostu ich notowań wobec szlachty i króla, do którego należało rozdawnictwo urzędów

${ }^{35}$ Ibidem, s. 395.

${ }^{36}$ Deputaci, s. 33.

${ }^{37}$ VL, t. 2, s. 402.

${ }^{38}$ A.S. Radziwiłł, Pamiętnik, t. 1, s. 537, 541. 
i dochodowych dzierżaw. Funkcja ta mogła pełnić rodzaj odskoczni i przyspieszenia awansu w hierarchii urzędniczej Wielkiego Księstwa. Warto zatem przyjrzeć się bliżej awansom urzędniczym poszczególnych marszałków z lat 1633-1648.

III. Spośród wszystkich 37 osób, które zostały marszałkami Trybunału Głównego, tylko 11 było u szczytu swoich karier urzędniczych. Byli to: podkomorzy wiłkomierski Aleksander Kaweczyński, marszałek grodzieński Jan Władysław Alexandrowicz, podkomorzy upicki Gabriel Białłozor, pisarz ziemski połocki Michał Tyszkiewicz, sędzia ziemski orszański Jan Ciechanowiecki, podkomorzy słonimski Gabriel Szemiot, pisarz polny litewski Mikołaj Krzysztof Sapieha, podkomorzy orszański Mikołaj Mleczko, podkomorzy wileński Jarosław Aleksander Szemiot, podkomorzy smoleński Samuel Stanisław Drucki Sokoliński i podwojewodzi wileński Stefan Karol Bielikowicz.

Pozostałych 26 marszałków awansowało jeszcze wyżej, wśród nich wszyscy marszałkowie-senatorowie. Krzysztof Chodkiewicz, który pojawił się po raz pierwszy jako marszałek w 1635 roku, awansował z kasztelani trockiej na urząd wojewody wileńskiego w 1642 roku i pełnił go aż do śmierci ${ }^{39}$. Mikołaj Kiszka otrzymał od Władysława IV kasztelanię trocką bezpośrednio po awansie Krzysztofa Chodkiewicza ${ }^{40}$, a już w 1640 roku został podskarbim wielkim litewskim $^{41}$. Jego brat, Krzysztof Kiszka z wojewody mścisławskiego został wojewodą witebskim w $1639 \mathrm{roku}^{42}$. Aleksander Słuszka awansował z wojewody nowogródzkiego na wojewodę trockiego jeszcze w lipcu 1642 roku $^{43}$, a więc $\mathrm{w}$ trakcie trwania kadencji wileńskiej, której przewodniczy ${ }^{44}$. Zmarł na tym urzędzie w lipcu $1647 \mathrm{roku}^{45}$. Antoni Jan Tyszkiewicz został senatorem w 1645 roku, obejmując urząd ministerialny - marszałka nadwornego, którym był również do śmierci ${ }^{46}$. Andrzej Stanisław Sapieha został przesunięty przez Władysława IV z kasztelanii trockiej na kasztelanię wileńską w marcu 1644 roku. Awansował zatem tuż przed rozpoczęciem sesji wileńskiej Trybunału, którą otwarto 11 kwietnia ${ }^{47}$. Natomiast Janusz Radziwiłł ze starosty generalnego żmudzkiego oraz hetmana polnego został wojewodą wileńskim i hetmanem wielkim. Pierwszym był od 1653 roku (po Krzysztofie Chod-

${ }^{39}$ R. Mienicki, Chodkiewicz Krzysztof, s. 369.

${ }^{40}$ Urzędnicy troccy, $\mathrm{nr} 528$.

${ }^{41}$ T. Wasilewski, Kiszka Mikołaj, PSB, t. 12, 1966-1967, s. 513; Urzędnicy centralni, nr 1220.

${ }^{42}$ Idem, Kiszka Krzysztof, PSB, t. 12, s. 510. O Krzysztofie Kiszce jako wojewodzie witebskim zob.: J. Zawadzki, Krzysztof Kiszka jako wojewoda witebski w latach 1639-1646, w: Litwa w epoce Wazów, red. W. Kriegseisen i A. Rachuba, Warszawa 2006, s. 219-235.

${ }^{43}$ Urzędnicy troccy, nr 1432.

${ }^{44}$ Kadencja wileńska trwała od 5 V do 6 IX 1642 roku (Deputaci, s. 237).

${ }^{45}$ M. Nagielski, Stuszka Aleksander, PSB, t. 39, 1999, s. 136.

${ }^{46}$ Urzędnicy centralni, $\mathrm{nr} 448$.

${ }^{47}$ Deputaci, s. 244. 
kiewiczu), a hetmanem wielkim został rok później ${ }^{48}$. Wszyscy oni doszli do najwyższych stanowisk świeckich, a Radziwiłł - ponadto - do najwyższego stanowiska wojskowego na Litwie.

Pozostałych 19 dyrektorów trybunalskich nie piastowało urzędu lub zajmowało tylko urzędy ziemskie. Spośród nich $8 \mathrm{w}$ przyszłości miało się dosłużyć godności senatorskich, wszyscy na stanowisku wojewody lub - wysoko postawionych w hierarchii senatorskiej - kasztelanów wileńskiego lub trockiego. Byli to: Jan Anzelm Wilczek, marszałek Trybunału w 1633 i 1639 roku ${ }^{49}$, który umarł jako kasztelan trocki w styczniu 1649 roku $^{50}$, Mikołaj Sapieha, kasztelan wileński od 1642 roku $^{51}$, Adam Maciej Sakowicz, wojewoda smoleński od 1658 roku $^{52}$, Krzysztof Zawisza, kasztelan wileński w 1669 ro$\mathrm{ku}^{53}$, Tomasz Sapieha, wojewoda nowogródzki na przełomie 1642-1643 roku ${ }^{54}$, Krzysztof Rudomina Dusiacki, który krzesło wojewody mińskiego otrzymał w lipcu 1654 roku, na kilkanaście miesięcy przed śmiercią ${ }^{55}$, Piotr Kazimierz Wiażewicz, wojewoda nowogródzki w 1653 roku ${ }^{56}$, Jakub Teodor Kuncewicz, wojewoda brzeski litewski od 1664 roku $^{57}$, oraz Mikołaj Walerian Ciechanowiecki, który nominację na wojewodę mścisławskiego otrzymał w 1659 ro$\mathrm{ku}^{58}$. Ten ostatni był - po wojnie ze Szwecją - jeszcze dwa razy marszałkiem Trybunału Głównego w 1665 i 1670 roku $^{59}$. Należy także wspomnieć o Kazimierzu Tyszkiewiczu. Jak informuje Albrycht Stanisław Radziwiłł, wakującą po awansie Andrzeja Massalskiego na wojewodę mińskiego, kasztelanię brzeską otrzymał 14 marca 1643 roku tamtejszy podkomorzy Kazimierz Tyszkiewicz ${ }^{60}$. Niemniej jednak w następnych latach dalej występuje on jako podkomorzy $^{61}$. Zapewne więc albo zaraz zrezygnował z niej, albo w ogóle jej nie przyjął, być może licząc $\mathrm{w}$ przyszłości na jakieś bardziej intratne propozycje królewskie. Zmarł w 1649 roku, prawdopodobnie nie mając nawet 40 lat $^{62}$.

\footnotetext{
${ }^{48}$ Urzędnicy centralni, nr 141; T. Wasilewski, Radziwilt Janusz, PSB, t. 30, 1987, s. 208.

${ }^{49}$ Deputaci, s. 209, 228.

${ }^{50}$ Urzędnicy troccy, $\mathrm{nr} 531$.

${ }^{51}$ Urzędnicy wileńscy, $\mathrm{nr} 386$.

${ }^{52}$ Urzędnicy smoleńscy, nr 1614.

${ }^{53}$ Urzędnicy wileńscy, nr 391.

${ }^{54}$ A. Rachuba, Sapieha Tomasz, PSB, t. 35, 1994, s. 154.

${ }^{55}$ H. Lulewicz, Rudomina Dusiacki Krzysztof, PSB, t. 32, 1991, s. 677.

56 J.A. Chrapowicki, Diariusz, część pierwsza: lata 1656-1664, oprac. T. Wasilewski, Warsza-

${ }^{57}$ T. Wasilewski, Kuncewicz Jakub Teodor, PSB, t. 16, s. 181.

${ }^{58}$ R. Mienicki, Ciechanowiecki Mikołaj Walerian, PSB, t. 4, 1938, s. 31.

${ }^{59}$ Deputaci, s. 294, 308.

${ }^{60}$ A.S. Radziwiłt, Pamiętnik, t. 2, s. 348.

${ }^{61}$ J. Wolf, Senatorowie, s. 100; VL, t. 4, s. 113.

${ }^{62}$ Podkomorzy brzeski Kazimierz Tyszkiewicz urodził się po 1609 roku. Jego ojcem był Jan Ostafi, więc Kazimierz był młodszym bratem Antoniego Jana, marszałka nadwornego litewskiego.
} wa 1978 , s. 118 . 
Spośród przedstawionych awansów na godności senatorskie szczególnie interesująco przedstawiają się kariery Piotra Kazimierza Wiażewicza i Jakuba Teodora Kuncewicza. Piotr Kazimierz Wiażewicz w początkowej fazie swojej bardzo bogatej kariery urzędniczej był protegowanym wojewody smoleńskiego Jerzego Karola Hlebowicza ${ }^{63}$. Wstawiał się za nim także kanclerz litewski Albrycht Stanisław Radziwiłł przed królową Cecylią Renatą, by ten ,został za jej pośrednictwem uhonorowany pisarstwem litewskim" ${ }^{64}$. Te starania się nie powiodły, bo pisarzem litewskim Wiażewicz nie $\operatorname{zosta}^{65}$. Zaliczył łącznie osiem urzędów ziemskich i grodzkich. Był m.in. trzy razy wójtem: w Mścisławiu, Orszy oraz Smoleńsku ${ }^{66}$. Był aktywny w życiu publicznym: dwukrotnie uczestniczył jako sekretarz w poselstwach do Moskwy (1635 i 1650) ${ }^{67}$. W 1635 roku przed pierwszym tam wyjazdem Władysław IV pisał do niego: „Żebyś z posłami naszymi za trzeciego wedle zwyczaju dawnego jechał" ${ }^{68}$. Wojewodą nowogródzkim został w 1653 roku, zapewne - w nagrodę za służbę dla Rzeczypospolitej. Zmarł 2 kwietnia 1657 roku $^{69}$. Jeszcze wyżej w hierarchii urzędniczej awansował Jakub Teodor Kuncewicz. W latach 1635-1660 zajmował on w powiecie lidzkim trzy kolejne urzędy ziemskie: pisarza, chorążego oraz podkomorzego ${ }^{70}$. W 1660 roku awansował na kasztelanie: mińską, a następnie żmudzką ${ }^{71}$ Trzy lata później został wojewodą brzeskim-litewskim. Urzędy ziemskie zawdzięczał zapewne protekcji Krzysztofa Radziwiłła, z którym był przez pewien czas związany $^{72}$. Następnie zbliżył się do dworu Jana Kazimierza ${ }^{73}$. Wcześniej, w latach dwudziestych XVII wieku jego karierą polityczną kierował Lew Sapieha $^{74}$. W czasie „potopu” poważnie zasłużył się dla Rzeczypospolitej, co było też główną przyczyną jego awansów na urzędy senatorskie. Zmarł 28 sierpnia 1668 roku $^{75}$. Obaj zatem korzystali z protekcji najbardziej wpływowych magnatów litewskich, by następnie usamodzielnić się i - wykorzystując swoje talenty w dyplomacji lub na wojnie - dojść do urzędów se-

${ }^{63}$ M. Sawicki, Stronnictwo dworskie w Wielkim Księstwie Litewskim w latach 1648-1655, Opole 2010, s. 36.

${ }^{64}$ A.S. Radziwiłl, Pamiętnik, t. 2, s. 131.

${ }^{65}$ Ibidem, s. 133.

${ }^{66}$ Urzędnicy smoleńscy, nr 1672.

${ }^{67}$ A.S. Radziwiłł, Pamiętnik, t. 1, s. 445 i t. 3, s. 242.

${ }^{68}$ Cyt. za: H. Wisner, Historia dyplomacji polskiej 1572-1795, red. G. Labuda, t. 2, Warszawa 1982, s.134.

${ }^{69}$ J.A. Chrapowicki, Diariusz, cz. I, s. 118.

${ }^{70}$ Urzędnicy wileńscy, nr 2146, 2449, 2534.

${ }^{71}$ T. Wasilewski, Kuncewicz Jakub Teodor, s. 181.

${ }^{72}$ U. Augustyniak, W stużbie hetmana i Rzeczypospolitej: klientela wojskowa Krzysztofa Radziwilta (1585-1640), Warszawa 2004, s. 294 (aneks).

${ }^{73}$ M. Sawicki, Stronnictwo, s. 179.

${ }^{74}$ T. Wasilewski, Kuncewicz Jakub Teodor, s. 180.

${ }^{75}$ Urzędnicy wileńscy, s. 680 (indeks nazwisk). 
natorskich. Tego typu przykłady karier urzędniczych w Wielkim Księstwie można mnożyćc ${ }^{76}$.

Nie licząc Kazimierza Tyszkiewicza, 10 osób, które były dyrektorami Trybunału Głównego w latach 1633-1648, nie osiągnęło nigdy godności senatorskich, co nie oznacza, że nie było wśród nich osób znaczących i wpływowych, choćby tylko w danym powiecie czy województwie. Na pierwsze miejsce pod tym względem wysuwa się zdecydowanie Samuel Aleksander Komorowski, jeden z marszałków kadencji wileńskiej w 1642 roku $^{77}$. Jego błyskotliwa kariera rozpoczęła się podczas wojny smoleńskiej 1632-1634, kiedy odznaczył się, stojąc na czele chorągwi husarskiej Krzysztofa Radziwiłła ${ }^{78}$. Jego pierwszy urząd, podczaszostwo wiłkomierskie, które otrzymał w 1635 roku, stanowiło zapewne nagrodę za zasługi położone w czasie tej wojny i służbę u Krzysztofa Radziwiłła, choć pierwotnie był „przewidywany” przez Piotra Kochlewskiego na wyższy urząd podstolego ${ }^{79}$. Od 1643 roku był już podstolim ${ }^{80}$. Później awanse i nadania przychodziły szybciej. W 1650 roku został chorążym, a już dwa lata później - starostą wiłkomierskim ${ }^{81}$. W tym okresie trzymał również starostwo niegrodowe mołczadzkie. Oprócz tego od 1654 roku tytułował się oboźnym Wielkiego Księstwa ${ }^{82}$. W czasie wojny ze Szwecją dowodził jako regimentarz lewym skrzydłem armii litewskiej $(1658)^{83}$. Od początku był związany politycznie i wojskowo z Radziwiłłami birżańskimi ${ }^{84}$. W walce o starostwo wiłkomierskie z Kazimierzem Ludwikiem Jewłaszewskim wygrał dzięki wsparciu Janusza Radziwiłła, który podburzał szlachtę przeciwko Jewłaszewskiemu ${ }^{85}$. Zostałby zapewne senatorem, lecz zmarł nagle, w dość niecodziennych okolicznościach, 20 października 1659 roku $^{86}$.

Pozostali marszałkowie Trybunału Głównego nie zrobili już większych karier, jeśli chodzi o stanowiska zarówno na szczeblu lokalnym jak i senatorskim. Jan Kazimierz Pac został pisarzem wielkim litewskim ${ }^{87}$, Marcjan Giedroyć awansował z podsędka na sędziego ziemskiego wileńskiego ${ }^{88}$, Władysław Monwid Dorohostajski został cześnikiem litewskim w 1638 roku

${ }^{76} \mathrm{O}$ układach klientalnych i roli przy obsadzie urzędników: A. Mączak, Klientela. Nieformalne systemy władzy w Polsce i Europie XVI-XVIII w., Warszawa 2000.

${ }^{77}$ Deputaci, s. 237.

${ }^{78}$ A. Przyboś, Komorowski Samuel Aleksander, PSB, t. 13, 1967-1968, s. 431.

${ }^{79}$ A. Rachuba, Kandydaci Piotra Kochlewskiego do nowych urzędów litewskich w 1635 roku, KH, r. 99, z. 1, 1992, s. 97.

${ }^{80}$ Urzędnicy wileńscy, $\mathrm{nr} 3524$.

${ }^{81}$ Ibidem, nr 2973, 3784.

${ }^{82}$ A. Przyboś, Komorowski Samuel Aleksander, s. 431.

${ }^{83}$ Ibidem, s. 432.

${ }^{84}$ U. Augustyniak, $W$ stużbie, s. 253.

${ }^{85}$ Urzędnicy wileńscy, nr 3783.

${ }^{86}$ A. Przyboś, Komorowski Samuel Aleksander, s. 433.

${ }^{87}$ J. Wolff, Pacowie, s. 73.

${ }^{88}$ Urzędnicy wileńscy, $\mathrm{nr} 922$. 
(w tym samym roku zmarł) ${ }^{89}$, Adam Owsiany awansował jedynie na sędstwo ziemskie lidzkie ${ }^{90}$, Aleksander Kazimierz Wołłowicz - na chorąstwo słonimskie, a Dymitr Bychowiec - również na sędstwo ziemskie trockie ${ }^{91}$. Michał Konstanty Kolenda zakończył karierę na sędstwie ziemskim wileńskim ${ }^{92}$, natomiast Stanisław Albrycht Zenowicz, który w 1645 roku był jeszcze bez urzędu, w przyszłości został wybrany na sędziego ziemskiego (1648) oraz podkomorzego oszmiańskiego $(1649)^{93}$.

Tak więc na 37 osób, które były marszałkami trybunalskimi, senatorami było lub w przyszłości miało zostać, wliczając Kazimierza Tyszkiewicza, 17 osób, czyli 46\% całej tej grupy. Licząc wszystkie awanse, czyli bez względu na rodzaj godności, aż 26 marszałków (70\%) awansowało. Co warte podkreślenia, większość awansów przychodziła już w rok, dwa lub trzy lata po pełnieniu funkcji dyrektora Trybunału albo w jej trakcie. To oczywiście nie oznacza, że bycie marszałkiem Sądu Głównego za Władysława IV gwarantowało automatycznie promocję na następny urząd, a już szczególnie, jeśli w grę wchodził urząd senatorski. Wówczas bowiem liczyły się głównie zasługi dla Rzeczypospolitej, nazwisko oraz upodobania królewskie i siła poszczególnych fakcji politycznych ${ }^{94}$. Można jednak postawić tezę, że pełnienie tej istotnej funkcji było jednym z elementów, które składały się na promocję w strukturach urzędniczych Wielkiego Księstwa. W interesie szlachty, która wybierała na sejmikach kandydatów na wakujące urzędy ziemskie, było posiadanie urzędników odpowiedzialnych i kompetentnych, z dobrą znajomością prawa, szczególnie, gdy chodziło o urzędy sędziów, podsędków, pisarzy czy podkomorzych ${ }^{95}$. Tak więc Trybunał Główny pełnił tutaj nie tylko funkcję najwyższej instancji sądowniczej na Litwie, ale także w pewnym sensie mógł lansować jednostki kompetentne, odpowiedzialne, jednocześnie dając im szanse podniesienia prestiżu wśród braci szlacheckiej.

IV. Analizując grupę marszałków Sądu Głównego, należałoby się przyjrzeć również kwestii wyznaniowej. W latach 1633-1648 sesjom Trybunału przewodniczyło 33 katolików, w tym - prawdopodobnie - trzech konwerty-

${ }^{89}$ S. Herbst, Dorohostajski Władysław, PSB, t. 5, 1939-1946, s. 335.

${ }^{90}$ Urzędnicy wileńscy, $\mathrm{nr} 2661$.

${ }^{91}$ Urzędnicy troccy, $\mathrm{nr} 1136$.

${ }^{92}$ Urzędnicy wileńscy, $\mathrm{nr} 925$.

${ }^{93}$ Ibidem, nr 1617, 1687.

${ }^{94}$ Najwyższe godności senatorskie w Wielkim Księstwie Litewskim były niejako od pokoleń zarezerwowane dla najbardziej wpływowych rodzin takich jak - przykładowo - Radziwiłłowie (linia birżańska i nieświeska), Sapiehowie, Chodkiewiczowie oraz Kiszkowie. Sytuacja ta zmieniła się dopiero w połowie XVII wieku, wówczas do tych godności - zarówno świeckich, jak i duchownych - dochodzili Pacowie, Kuncewiczowie, Zenowiczowie, Frąckiewiczowie Radzimińscy, Wołodkiewiczowie, Wołłowiczowie oraz Ciechanowieccy.

${ }^{95}$ Inna sprawa, że nominacje na urzędy stanowiły często rozgrywkę między fakcjami, przy tym niekoniecznie kierowano się kompetencjami wysuwanych kandydatów. 
tów z kalwinizmu ${ }^{96}$, trzech kalwinistów i tylko jeden prawosławny. Na pewno katolikami w okresie panowania Władysława IV byli poza innymi: Aleksander Kaweczyński, konwertyta z kalwinizmu, który zmarł w czerwcu 1633 roku $^{97}$, czyli podczas kadencji wileńskiej, której był jednym z marszałków ${ }^{98}$ i Aleksander Słuszka, w młodości z woli ojca kalwinista, potem od 1611 roku katolik $^{99}$. Podkomorzy orszański Mikołaj Mleczko jeszcze około 1619 roku dokonał zapisów dla zboru wileńskiego ${ }^{100}$, następnie ,pod starość widocznie gorliwy katolik", który fundował klasztor karmelitów w Chołopieniczach w $1640 \mathrm{roku}^{101}$. Marszałkiem Trybunału w 1638 roku był jako katolik.

Nieco bardziej złożenie przedstawia się kwestia wyznania Stefana Karola Bielikowicza. W momencie piastowania funkcji marszałka Trybunału na pewno był on katolikiem ${ }^{102}$. Istnieją jednak fakty, które wskazują na jego powiązania z kalwinizmem. Przede wszystkim to, że był żonaty najpierw z Zofią Wolanówną, a potem z Aleksandrą z Korsaków. Zarówno Wolanowie jak i Korsakowie byli objęci wpływami reformacji ${ }^{103}$. Dodatkowo Bielikowicz otrzymał urząd podczaszego oszmiańskiego, który scedował mu w 1644 roku za zgodą króla, kalwinista Samuel Pawłowicz Osiński ${ }^{104}$. To jednak, rzecz jasna, nie przesądza o tym, że był dysydentem, choć kontakty z dysydentami były tu wyraźne. Jeśli nim jednak był, to również wcześnie dokonał konwersji, tym bardziej że podwojewodzim wileńskim został z ramienia wojewody wileńskiego i katolika Krzysztofa Chodkiewicza.

Głębszej analizy wymaga również kwestia konfesji Jana Anzelma Wilczka. Miał on być kalwinistą przed 1637 rokiem, a następnie dokonać konwer$\mathrm{sji}^{105}$. Jak zanotował kanclerz Radziwiłł, Wilczek podpisał wraz z innymi stronnikami wojewody wileńskiego i hetmana wielkiego Krzysztofa Radziwiłła, protestację przeciwko duchownym katolickim po niedoszłej do skutku korekturze Statutu litewskiego w 1636 roku $^{106}$. Zrobił to jednak jako katolik, pamiętnikarz wymienia go bowiem wyraźnie jako jednego z 5 katolików,

${ }^{96}$ Być może związki z kalwinizmem miał również Samuel Aleksander Komorowski, który jednorazowo występuje w aktach synodalnych Jednoty litewskiej w roku 1636 (Akta synodów prowincjonalnych Jednoty Litewskiej 1626-1637, wstęp i oprac. M. Liedke i P. Guzowski, Warszawa 2011, s. 157).

${ }^{97}$ Urzędnicy wileńscy, nr 3452.

${ }^{9}$ Deputaci, s. 209.

${ }^{99}$ M. Nagielski, Stuszka Aleksander, s. 134.

100 S. Uruski, Rodzina, t. 11, s. 143.

101 Ibidem.

102 T. Wasilewski, Tolerancja religijna $w$ Wielkim Księstwie Litewskim $w$ XVI-XVII wieku, ,Odrodzenie i Reformacja w Polsce" (dalej: OiRwP), t. 19, 1974, s. 124.

103 S. Konarski, Szlachta kalwińska w Polsce, Warszawa 1936 [reprint 1993], s. 141, 319; M. Liedke, Od prawosławia do katolicyzmu. Ruscy możni i szlachta Wielkiego Księstwa Litewskiego wobec wyznań reformacyjnych, Białystok 2004, s. 90, 197.

${ }^{104}$ Urzędnicy wileńscy, nr 1629.

105 H. Lulewicz, Skład wyznaniowy senatorów świeckich Wielkiego Księstwa Litewskiego za panowania Wazów, „Przegląd Historyczny”, t. 63, z. 3, 1977, s. 437.

${ }^{106}$ A.S. Radziwiłł, Pamiętnik, t. 1, s. 539. 
którzy tę protestację podpisali ${ }^{107}$. Zatem był on katolikiem już przynajmniej od 1636 roku. Być może w ogóle nie był nigdy ewangelikiem, ponieważ na kartach pamiętnika ani razu Radziwiłł nie wspomina o nim jako kalwiniście. W latach 1627-1636 nie ma go też w aktach synodów prowincjonalnych Wielkiego Księstwa Litewskiego. Dodatkowo: jego jedyny, zmarły młodo, syn z pierwszej żony Anny Oziembłowskiej, Aleksander, już w 1631 roku uczył się w akademii wileńskiej ${ }^{108}$. Raczej mało prawdopodobne, by mógł na naukę posłać go tam wyznawca kalwinizmu.

Innowiercami byli: Janusz Radziwiłł, Marcjan Giedroyć, Władysław Monwid Dorohostajski i Dymitr Bychowiec. Hetman wielki litewski i wojewoda wileński był kalwinistą do końca życia, choć po śmierci Krzysztofa, swojego ojca i pierwszego kalwinisty na Litwie ${ }^{109}$, chodziła pogłoska, że zamierza pod wpływem swojej pierwszej żony i gorliwej katoliczki Katarzyny Potockiej, przejść na „wiarę rzymską?" ${ }^{110}$. Marcjan Giedroyć, który był ewangelikiem w 1612 roku $^{111}$, występuje w aktach synodów prowincjonalnych Jednoty Litewskiej jeszcze w 1636 roku $^{112}$. Nie wiadomo, czy dokonał konwersji przed śmiercią. W każdym razie już po śmierci Giedroycia w 1649 roku, obok wdowy po nim, występują kalwiniści Jerzy Stabrowski, syn Piotra, kasztelana parnawskiego oraz Mikołaj Puciata ${ }^{113}$. Gorliwym kalwinistą był Władysław Monwid Dorohostajski, syn Krzysztofa, marszałka wielkiego litewskiego ${ }^{114}$, który w 1636 roku był proszony o objęcie seniorstwa zboru wileńskiego ${ }^{115}$. Jedynym więc marszałkiem, który reprezentował prawosławną część szlachty był w 1646 roku podsędek trocki Dymitr Bychowiec ${ }^{116}$. Trzymanie się prawosławia przez niektórych przedstawicieli rodziny Bychowców aż do połowy XVII stulecia było możliwe dzięki związkom, jakie łączyły ich z wpływowymi - między innymi - w województwie trockim Ogińskimi, którzy obok Stetkiewiczów, byli głównymi protektorami prawosławia na Litwie ${ }^{117}$.

${ }^{107}$ Ibidem, s. 539.

${ }^{108}$ K. Niesiecki, Herbarz Polski Kaspra Niesieckiego powiększony dodatkami z późniejszych autorów, rękopisów, dowodów urzędowych, t. 9, Lipsk 1842, s. 331.

${ }^{109}$ A.S. Radziwiłl, Pamiętnik, t. 2, s. 223.

${ }^{110}$ T. Wasilewski, Radziwiłt Janusz, PSB, t. 30, 1989, s. 210. Jego „przygoda” z katolicyzmem skończyła się zapewne w 1642 roku, wraz ze śmiercią pierwszej żony i gorliwej katoliczki - Katarzyny Potockiej.

${ }^{111}$ H. Wisner, Kilka uwag o stronnictwie wojewody wileńskiego Krzysztofa Radziwitla (1585-1640), „Zapiski Historyczne”, t. 62, z. 4, 1997, s. 42.

${ }^{112}$ Akta synodów, s. 151, 168: J. M. P. podsędek wileński 1000 złotych na zbór połocki od P. Janowej Puciacinej Anny Tyszkiewiczówny legowane oddat, na co kwitację otrzymat.

113 J. Wolff, Kniaziowie, s. 72.

${ }^{114}$ S. Herbst, Dorohostajski Wtadystaw, s. 335.

${ }^{115}$ Akta synodów, s. 142.

${ }^{116}$ Deputaci, s. 251.

${ }^{117}$ T. Kempa, Kariery przedstawicieli prawosławnych rodów Ogińskich i Stetkiewiczów w XVII wieku - podobieństwa i różnice awansu społecznego, ekonomicznego i politycznego, w: Władza i prestiż: magnateria Rzeczypospolitej w XVI-XVIII wieku, red. J. Urbanowicz, Białystok 2003, s. 347. 
Zdecydowaną więc część marszałków trybunalskich (89\%) stanowili katolicy. Ich przewaga jest jeszcze większa, jeśli weźmiemy pod uwagę fakt, że wszyscy niekatoliccy marszałkowie z wyjątkiem Władysława Monwida Dorohostajskiego byli wybierani tylko na jedną kadencję. Również Janusz Radziwiłł był przecież tylko marszałkiem w Wilnie z powodu nieodbycia się planowej kadencji mińskiej w 1648 roku. Interesujące jest natomiast to, że niekatoliccy dyrektorowie Trybunału Głównego byli wybierani w latach 1634, 1636 i 1646, 1648. W pierwszym przypadku może to się wiązać z bardzo silną pozycją Krzysztofa Radziwiłła. W drugim - być może - zjawisko to jest związane z faworyzowaniem przez Władysława IV w ostatnich trzech latach swojego panowania dysydentów i prawosławnych, których monarcha chciał pozyskać do realizacji koncepcji niezależnego od Konstantynopola patriarchatu wschodniego ${ }^{118} \mathrm{i}$ wiążących się z tym planów wojny z Turcją. Wydaje się to jednak mało prawdopodobne, bo król nie zawsze miał wpływ na to, kto zostawał deputatem do Trybunału, a plany dworskie nierzadko rozmijały się z dążeniami stanu szlacheckiego. Bardziej prawdopodobne jest, że rosnąca pozycja Janusza Radziwiłła, który od 1646 roku był już starostą generalnym żmudzkim i hetmanem polnym, przyczyniła się do krótkotrwałego wzrostu wpływów szlachty nie tylko ewangelickiej, ale i prawosławnej.

Porównując stanowiska marszałka Trybunału Głównego Litewskiego i marszałka izby poselskiej w analogicznym okresie, okazuje się, że pod względem wyznaniowym nieco bardziej pluralistyczna była funkcja marszałka Trybunału. W drugiej połowie panowania Władysława IV, którego rządy charakteryzowała największa spośród polskich Wazów tolerancja wyznanio$\mathrm{wa}^{119}$, mamy tylko jednego marszałka poselskiego z obozu dysydenckiego, i do tego Polaka. Był nim w 1641 roku brat czeski Bogusław Leszczyński ${ }^{120}$. Na 15 marszałków niższej izby za panowania tego władcy był on jedynym niekatolikiem $^{121}$. Być może większy udział innowierców w piastowaniu funkcji dyrektora Trybunału litewskiego był spowodowany mniej gwałtownym postępem kontrreformacji na Litwie niż w Koronie ${ }^{122}$. Nie bez znaczenia była też silna pozycja Radziwiłłów birżańskich, głównych opiekunów politycznych i finansowych Jednoty Litewskiej ${ }^{123}$.

Rozpatrując ,pochodzenie sejmikowe” marszałków trybunalskich - w przypadku sześciu osób nie mamy pewności, z których sejmików zostały one wy-

${ }^{118}$ T. Wasilewski, Tolerancja religijna, s. 125.

${ }^{119}$ T. Kempa, Kariery przedstawicieli, s. 347.

${ }^{120}$ J. Seredyka, W. Kaczorowski, Marszałkowie poselscy za panowania Wtadystawa IV Wazy w: Kultura, polityka, dyplomacja. Studia ofiarowane Profesorowi Jaremie Marciszewskiemu w sześćdziesiąta rocznicę Jego urodzin, Warszawa 1990, s. 358-359.

${ }^{121}$ Ibidem, s. 360-361.

122 M. Kosman, Litewska Jednota Ewangelicko-Reformowana od połowy XVII wieku do 1939 roku, Opole 1986, s. 10.

${ }^{123}$ H. Wisner, Likwidacja zboru ewangelickiego w Wilnie (1639-1646), OiRwP, t. 37, 1993, s. 91. 
brane. Chodzi tu o osoby z rodów pierwszoplanowych na Litwie: Jana Kazimierza Paca, Aleksandra Słuszkę, Krzysztofa Chodkiewicza, Tomasza i Andrzeja Stanisława Sapiehów oraz Janusza Radziwiłła. Możemy jednak na podstawie pełnionych urzędów oraz przynależności fakcyjnej w większości przypadków przypuszczać, na których sejmikach ich delegowano. Jan Kazimierz Pac prawdopodobnie był deputatem z województwa połockiego, gdzie posiadał dobra ${ }^{124}$. W przypadku Aleksandra Słuszki w 1642 roku nie znamy kompletu deputatów z Lidy, Nowogródka i Mozyrza ${ }^{125}$. Przypuszczalnie był on deputatem nowogródzkim, po pierwsze: z racji pełnienia urzędu wojewody nowogródzkiego, a po drugie: $\mathrm{z}$ racji utrzymywania przyjaznych kontaktów z Radziwiłłami birżańskimi ${ }^{126}$. Drugim deputatem z tego sejmiku był chorąży nowogródzki Matiasz (Maciej) Frąckiewicz Radzimiński - kalwinista i klient birżańskiej linii Radziwiłłów ${ }^{127}$. Podobnie wygląda rzecz z Krzysztofem Chodkiewiczem w 1635 roku, który z racji pełnienia urzędu kasztelana trockiego mógł być wybrany na deputata na sejmiku upickim. Drugim miejscem jego wyboru mógł być Starodub, ponieważ z tego sejmiku także nie znamy kompletu deputatów ${ }^{128}$. W 1643 roku Chodkiewicz prawdopodobnie został deputatem wileńskim, jako że był już wtedy tamtejszym wojewodą. Przypuszczalnie w 1639 i na pewno w 1647 roku był deputatem z powiatu mozyrskiego ${ }^{129}$. Niewykluczone bowiem, że Chodkiewicze mieli tam swoich reprezentantów, którzy dbali o ich interesy. W każdym razie istniała przez długi okres czasu podstawa, by oddziaływać na ogół szlachty, albowiem jego najmłodszy syn Hieronim Karol, urodzony w 1618 roku, piastował urząd starosty grodowego mozyrskiego, którym został „dość wcześnie”"130.

Andrzej Stanisław Sapieha prawdopodobnie został deputatem w 1644 roku z Grodna, gdzie w latach 1620-1630 był wójtem ${ }^{131}$. Jeśli chodzi o Tomasza Sapiehę, to na pewno był on deputatem z województwa wileńskiego, ponieważ w 1640 roku brakuje kompletu deputatów tylko z sejmików oszmiańskiego i lidzkiego ${ }^{132}$. Prawdopodobnie był deputatem z sejmiku powiatu oszmiańskiego, gdzie leżały Holszany. Kierując się geografią wpływów poszczególnych fakcji, można również ustalić domniemane miejsce wyboru Janusza Radziwiłła. Zapewne był to Wiłkomierz, który obok Nowogródka był miejscem, z którego wielokrotnie posłowali Radziwiłłowie birżańscy ${ }^{133}$,

\footnotetext{
${ }^{124}$ J. Wolff, Pacowie, s. 72-74.

${ }^{125}$ Deputaci, s. 238, 239, 240.

${ }^{126}$ M. Nagielski, Stuszka Aleksander, s. 135.

${ }^{127}$ U. Augustyniak, $W$ stużbie, s. 335 (aneks).

${ }^{128}$ Deputaci, s. 216.

${ }^{129}$ Ibidem, s. 256.

${ }^{130}$ Cyt. za: L. Podhorodecki, Dzieje rodu Chodkiewiczów, Warszawa 1997, s. 124.

${ }^{131}$ Urzędnicy troccy, $\mathrm{nr} 2485$.

${ }_{132}$ Deputaci, s. 231.

133 J. Seredyka, Udziat Radziwittów w sejmach za panowania Zygmunta III Wazy, „Miscellanea Historico-Archivistica" (dalej: MHA), t. 3, 1989, s. 24-25.
} 
a tamtejszy sejmik był w pierwszej połowie XVII wieku jednym z bardziej reprezentatywnych wśród sejmików stronnictwa radziwiłłowskiego ${ }^{134}$.

Generalnie: marszałkowie Trybunału byli wybierani na deputatów na sejmikach „górnych województw” mających wysoką rangę i pozycję wśród sejmików litewskich, głównie z województwa wileńskiego. Na sejmiku lidzkim byli wybierani: Adam Owsiany, Jakub Teodor Kuncewicz (dwa razy), z Oszmiany: Jan Anzelm Wilczek (dwa razy), Adam Maciej Sakowicz, Krzysztof Kiszka, Mikołaj Krzysztof i Tomasz Sapiehowie, Stanisław Albrycht Zenowicz, z Wiłkomierza: Aleksander Kaweczyński i Samuel Aleksander Komorowski, a z Brasławia - Krzysztof Rudomina Dusiacki. Z samego Wilna deputatami, oprócz wyżej już wspomnianego Krzysztofa Chodkiewicz, byli także: Marcjan Giedroyć, Gabriel Szemiot, Antoni Jan Tyszkiewicz (trzy razy), Stefan Karol Bielikowicz i Michał Konstanty Kolenda. Łącznie na 45 marszałków Trybunału Głównego, 20 pochodziło z sejmików województwa wileńskiego, co stanowi 44\% wszystkich dyrektorów Trybunału z lat 16331648. Jest to całkiem poważny odsetek. Nie powinno to jednak dziwić, całościowo bowiem województwo wileńskie, a szczególnie samo Wilno, stanowiło centralną arenę zmagań politycznych w Wielkim Księstwie Litewskim. Wyjątkiem jest tu tylko sejmik brasławski, który był raczej sejmikiem peryferyjnym i do tego jeszcze niezbyt licznym ${ }^{135}$.

Z powiatów orszańskiego i słonimskiego udało się zostać marszałkami łącznie pięciu deputatom, którymi byli: Mikołaj Sapieha, Aleksander Kazimierz Wołłowicz (wybrani w Słonimiu) oraz Mikołaj Mleczko, Mikołaj Walerian i Jan Ciechanowieccy (wybrani w Orszy). Najprawdopodobniej żaden deputat wybrany na sejmiku w Kownie, Żmudzi (Rosieniach), Starodubiu, Witebsku, Pińsku, Mścisławiu, Mińsku i Rzeczycy nie został dyrektorem Trybunału.

Nieprzypadkowo jedyny prawosławny marszałek Trybunału, Dymitr Bychowiec, był deputatem $\mathrm{z}$ Trok ${ }^{136}$. Swoje posiadłości w województwie trockim posiadali nie tylko Bychowcowie, ale również Stetkiewicze (Steckiewicze) oraz Ogińscy, główni patroni i obrońcy wiary prawosławnej na Litwie w XVII wieku ${ }^{137}$. Ponadto przedstawiciele tych rodzin pełnili w tym województwie wiele urzędów ${ }^{138}$, co dodatkowo świadczy o ich wpływach wśród szlachty trockiej. Zapewne nieprzypadkowe było też to, że Dymitr Bychowiec został marszałkiem nie w Wilnie, ale w Nowogródku, gdzie w związku z pozycją, jaką posiadała tam linia birżańska Radziwiłłów, klimat dla marszał-

${ }^{134}$ J. Dzięgielewski, Radziwillowie posłami sejmów w czasach Władysława IV, MHA, t. 3, s. 31.

${ }^{135}$ A.B. Zakrzewski, Sejmiki Wielkiego Księstwa Litewskiego XVI-XVIII w. Ustrój i funkcjonowanie: sejmik trocki, Warszawa 2000, s. 10.

${ }^{136}$ Deputaci, s. 251.

${ }^{137}$ T. Kempa, Kariery przedstawicieli, s. 348.

${ }^{138}$ Urzędnicy troccy, s. 570, 626, 654 (indeks nazwisk). 
ka niekatolickiego był znacznie lepszy. Może to stanowić kolejny przykład aliansu między ewangelikami i prawosławnymi, którzy często w przeszłości współpracowali ze sobą dla osiągnięcia wspólnych korzyści ${ }^{139}$.

V. Na koniec rozważań o osobach pełniących urząd marszałka trybunalskiego nie sposób nie wspomnieć o bardzo istotnej kwestii orientacji politycznej owych osób. Bez wątpienia główne stronnictwa polityczne Litwy za panowania Władysława IV, skupione wokół potężnych, antagonistycznie nastawionych do siebie familii Radziwiłłów (fakcje linii birżańskiej i nieświeskiej), Sapiehów ${ }^{140}$, a także osób związanych z dworem królewskim, w dużej mierze decydowały o tym, kto był wybierany na posła czy deputata na sejmikach, choć mogły mieć miejsce incydentalne przypadki lokalnych liderów politycznych niezwiązanych z fakcjami magnackimi ${ }^{141}$. Warto było bowiem posiadać licznych sojuszników wśród sędziów trybunalskich ${ }^{142}$, którzy przecież wydawali dekrety, mogące dotyczyć - pośrednio lub bezpośrednio - także interesów polityczno-majątkowych pierwszoplanowych postaci litewskiej sceny politycznej.

W roku 1633 marszałkiem wybranym w dniu inauguracji sądów został Jan Kazimierz Pac, najprawdopodobniej zaliczający się już wtedy do stronników królewskich, podobnie zresztą jak inni przedstawiciele jego rodziny ${ }^{143}$. Pozostałymi marszałkami byli: Aleksander Kaweczyński, Jan Anzelm Wilczek i Jan Władysław Alexandrowicz. Pierwszy pochodził z rodziny, których wielu przedstawicieli służyło już w II połowie XVI wieku w majętnościach Mikołaja Radziwiłła Czarnego, a następnie jego syna Mikołaja Krzysztofa Sierotki ${ }^{144}$, czyli linii nieświeskiej. Część również związała się z linią birżańską. Wśród nich Aleksander Kaweczyński ${ }^{145}$. Zmarł w młodzieńczym wieku, prawdopodobnie w czerwcu 1633 roku $^{146}$. W jego pogrzebie uczestniczy-

${ }^{139}$ Chyba najbardziej współpraca wyznawców religii niekatolickich uwidoczniła się podczas sejmu konwokacyjnego 1632, kiedy wspólnymi siłami niekatolikom udało się w postulatach końcowych umieścić zapisy o pokoju wyznaniowym w czasie bezkrólewia oraz żądanie potwierdzenia zapisów konfederacji warszawskiej (1573) dotyczących praw innowierców, zob.: T. Kempa, Wobec kontrreformacji. Protestanci i prawosławni w obronie swobód wyznaniowych $w$ Rzeczypospolitej w końcu XVI i w pierwszej połowie XVII wieku, Toruń 2007, s. 377-424.

${ }^{140}$ H. Lulewicz, Elita polityczno-społeczna Wielkiego Księstwa Litewskiego w połowie XVII wieku, praca doktorska w Bibliotece Instytutu Historii Uniwersytetu Warszawskiego, Warszawa 1984 , s. 315.

${ }^{141}$ A. Rachuba, Wielkie Księstwo Litewskie w systemie parlamentarnym Rzeczypospolitej w latach 1569-1763, Warszawa 2002, s. 120.

${ }^{142}$ H. Wisner, Kilka uwag, s. 35-36.

${ }^{143}$ A. Rachuba, Kandydaci, s. 94.

144 T. Kempa, Urzędnicy i klienci Mikołaja Krzysztofa Radziwilla Sierotki, „Lituano-Slavica Posnaniensia”, t. 9, 2003, s. 205-206.

${ }^{145}$ Ibidem, s. 208.

${ }^{146}$ Urzędnicy wileńscy, nr 3452. 
li zarówno kanclerz Albrycht Stanisław Radziwiłł jak i wojewoda wileński Krzysztof, który ze względów wyznaniowych „przybył tylko pod kościół”147.

Jan Anzelm Wilczek był wieloletnim sługą Krzysztofa Radziwiłła. Jego służba sięgała co najmniej 1620 roku, kiedy jako deputat i marszałek podpisał korzystny dla hetmana wyrok w głośnym konflikcie z Wolmarem Farensbachem ${ }^{148}$. Wielokrotnie był wybierany na deputata do Trybunału oraz posła na sejm, gdzie dbał o interesy Radziwiłła. Tak jeszcze w 1636 roku podczas niedoszłej do skutku poprawy Statutu litewskiego, wraz z innymi stronnikami wojewody wileńskiego, podpisał protestację przeciw duchownym katolic$\mathrm{kim}^{149}$. Po śmierci swego protektora nie kontynuował jednak służby u Janusza Radziwiłła, zbliżając się bardziej do dworu Wazów, co też uwidoczniło się w rychłych nominacjach senatorskich, w tym na wysoki urząd kasztelana trockiego ${ }^{150}$. Trudno z całą pewnością stwierdzić natomiast, jaką orientację polityczną miał marszałek grodzieński Jan Władysław Alexandrowicz. Wiadomo, że na sejmiku przedsejmowym grodzieńskim w 1641 roku miał on zwadę z krajczym litewskim Gedeonem Michałem Tryzną, który nasyłając służbę na niego i jego syna, ,syna wielokrotnie poranił, a ojca ledwo nie zabił"151. Gedeon Tryzna wchodził w orbitę wpływów zarówno sapieżyńskich jak i królewskich ${ }^{152}$. Wysuwanie na tej podstawie wniosku, że Jan Władysław Alexandrowicz zaliczał się do przeciwników sapieżyńskich jest chyba zbyt daleko idące, tym bardziej że nic nie wskazuje na jego współpracę z Radziwiłłami, dla których sejmik grodzieński w tym okresie nie stanowił domeny wpływów na Litwie. Być może Alexandrowicz był regalistą. Wskazuje na to pełnienie przez 17 lat wysokiego w hierarchii ziemskiej i istotnego w lokalnej polityce urzędu marszałka powiatowego ${ }^{153}$, który w tym okresie nie był elekcyjny, tak jak inne urzędy ziemskie, lecz pochodził wprost z nominacji królewskiej $^{154}$.

W 1634 roku marszałkami Trybunału zostali kolejno: chorąży wielki litewski Mikołaj Sapieha, Adam Maciej Sakowicz i Marcjan Giedroyćc ${ }^{155}$. Znamienny jest fakt, że w trakcie nieobecności w Trybunale Sapiehy na marszałka został wybrany Adam Maciej Sakowicz, jawny i wieloletni klient Radziwiłłów

${ }^{147}$ A.S. Radziwiłł, Pamiętnik, t. 1, s. 315.

148 U. Augustyniak, W stużbie, s. 117.

149 A.S. Radziwiłł, Pamiętnik, t. 1, s. 539.

${ }^{150}$ Urzędnicy troccy, $\mathrm{nr} 531$.

${ }^{151}$ A.S. Radziwiłl, Pamiętnik, t. 2, s. 251.

${ }^{152}$ M. Sawicki, Stronnictwo, s. 50; J. Dzięgielewski, Izba poselska w systemie władzy Rzeczypospolitej czasów Władysława IV, Warszawa 1990, s. 128.

${ }^{153}$ Urzędnicy troccy, $\mathrm{nr} 1770$.

${ }^{154}$ A.B. Zakrzewski, Marszalek powiatowy Wielkiego Księstwa Litewskiego marszałkiem sejmikowym (XVI-XVIII w.), w: Parlament, prawo, ludzie. Studia ofiarowane Profesorowi Juliuszowi Bardachowi w sześćdziesięciolecie pracy twórczej, Warszawa 1996, s. 356.

${ }^{155}$ Deputaci, s. 212. 
birżańskich, wielokrotny poseł na sejm i deputat do Trybunału, będący jednym z wybitniejszych parlamentarzystów litewskich swego czasu ${ }^{156}$. Klientem panów na Birżach i Dubinkach był także Marcjan Giedroyć. W 1612 roku był on jednym z dwóch kandydatów Krzysztofa Radziwiłła do wakującego urzędu chorążego wileńskiego obok Marcjana Górskiego ${ }^{157}$. Ponadto wydał on swoją córkę Cecylię za Mikołaja Puciatę ${ }^{158}$, kolejnego wieloletniego sługę Radziwiłłów birżańskich, pochodzącego z rodziny wyznającej kalwinizm ${ }^{159}$.

Inaczej przedstawiał się skład marszałków Trybunału w 1635 roku. Dyrektorami byli wtedy: Krzysztof Chodkiewicz, Gabriel Białłozor i Michał Tyszkiewicz. Krzysztof Chodkiewicz był - ze względu na liczne i absorbujące czas procesy majątkowe - mało zaangażowany w politykę, choć niewątpliwie musiał cieszyć się względami królewskimi, na co wskazują jego awanse urzędnicze, w tym na najwyższy świecki w hierarchii litewskiej urząd wojewody wileńskiego. W każdym razie raczej na pewno nie łączyły go przyjazne kontakty ani z Sapiehami, ani z Radziwiłłami, albowiem z obu rodami procesował się o dobra ${ }^{160}$. Gabriel Białłozor natomiast pochodził z rodziny związanej z dworem królewskim ${ }^{161}$. Sam był „pułkownikiem wojsk królewskich”162, także jego syn Kazimierz Karol był rotmistrzem w dywizji żmudzkiej w czasie wojny ze Szwecją w latach 1655-1660 ${ }^{163}$. Do stronników sapieżyńskich zaliczał się Michał Tyszkiewicz. W 1611 roku pełnił on urząd sędziego grodzkiego połockiego ${ }^{164} \mathrm{z}$ ramienia wojewody Andrzeja Sapiehy, piastującego tę godność w latach $1597-1613^{165}$.

W 1636 roku Trybunałowi przewodniczył stronnik Krzysztofa Radziwiłła oraz dwóch sprzymierzeńców sapieżyńskich. Stronnikiem radziwiłłowskim był cześnik litewski Władysław Monwid Dorohostajski, który „bez konkurenta został prawie wszystkimi głosami wybrany"166 i jak - stwierdził Albrycht Stanisław Radziwiłł: „za radą wojewody”167. W roli marszałka Trybunału stanowił on poważnego sojusznika, szczególnie jeśli chodziło o sprawy wyznaniowe. Tym bardziej że na miesiąc przed inauguracją kadencji wileńskiej rozpoczynała swoją pracę komisja do korektury Statutu litewskiego, w ob-

${ }^{156}$ Zobacz: M. Nagielski, Sakowicz Adam Maciej, PSB, t. 34, 1993, s. 334-339.

${ }^{157}$ H. Wisner, Kilka uwag, s. 42; Ostatecznie chorążym został Górski (Urzędnicy wileńscy, nr 211).

158 J. Wolff, Kniaziowie, s. 72.

${ }^{159}$ A. Rachuba, Kandydaci, s. 98.

${ }^{160}$ M. Sawicki, Stronnictwo, s. 69; L. Podhorodecki, Dzieje rodu, s. 114-119.

${ }^{161}$ Ibidem, s. 57.

${ }^{162}$ S. Uruski, Rodzina, t. 1, s. 163.

${ }^{163}$ E. Latacz, Białtozor Kazimierz, PSB, t. 2, 1936, s. 9-10; A. Rachuba, Konfederacje wojska litewskiego w latach 1655-1663, Zabrze 2010, s. 102 przyp. 29, s. 104 przyp. 41.

${ }^{164}$ Deputaci, s. 143.

165 J. Wolff, Senatorowie, s. 46; M. Nagielski, Sapieha Andrzej, PSB, t. 34, s. 572-574.

166 A.S. Radziwiłt, Pamiętnik, t. 1, s. 529.

${ }^{167}$ Ibidem, s. 540; chodzi o wojewodę wileńskiego Krzysztofa Radziwiłła. 
radach której uczestniczył również od 18 marca wojewoda wileński ${ }^{168} . \mathrm{Na}$ pozostałych marszałków zostali wybrani: w Wilnie - Jan Ciechanowiecki i w Nowogródku - Gabriel Szemiot. Obaj pochodzili z rodzin, których protektorami byli Sapiehowie ${ }^{169}$. Pierwszy był między innymi posłem z powiatu orszańskiego na sejm koronacyjny Władysława IV w 1633 roku. Z tego samego sejmiku drugim posłem został Kazimierz Leon Sapieha, wtedy jeszcze pisarz wielki litewski ${ }^{170}$. Gabriel Szemiot także był posłem na kilku sejmach i reprezentował interesy sapieżyńskie ${ }^{171}$, a dodatkowo jego rodzina była spowinowacona ze swoimi protektorami, o czym dalej.

W latach 1637-1638 dyrektorami Trybunału byli Kiszkowie. Najpierw Mikołaj Kiszka, a rok później - jego młodszy brat Krzysztof. Obaj, wspólnie z wojewodą połockim Januszem Kiszką, zaliczali się do stronników politycznych Radziwiłłów ${ }^{172}$ i dbali o ich interesy na sejmikach, a także w czasie konwokacji i elekcji w 1632 roku. Dodatkowo byli z nimi spowinowaceni. Krzysztof poślubił w 1618 roku Elżbietę Radziwiłłównę, córkę Mikołaja Krzysztofa Sierotki ${ }^{173}$, a Mikołaj Barbarę, córkę marszałka wielkiego litewskiego Albrychta Radziwiłła ${ }^{174}$. Prócz Krzysztofa Kiszki, marszałkami w 1638 roku byli: Mikołaj Krzysztof Sapieha, ponownie Jan Władysław Alexandrowicz, Mikołaj Mleczko i Antoni Jan Tyszkiewicz. Mikołaj Mleczko pochodził z rodziny, która związała swoją karierę z dworem królewskim Wazów ${ }^{175}$. Sam musiał się jednak zaliczać do bliskich sług Lwa Sapiehy, skoro pełnił z jego ramienia urząd podwojewodziego wileńskiego w latach $1625-1628^{176}$. Stronnikiem sapieżyńskim najprawdopodobniej był także Antoni Jan Tyszkiewicz, który w czasie bezkrólewia 1648 roku skwapliwie informował podkanclerzego Kazimierza Leona Sapiehę o bieżących sprawach politycznych, jednocześnie zapewniając o swej lojalności wobec podkanclerzego ${ }^{177}$.

Trybunałowi Głównemu z 1639 roku przewodniczyli po raz kolejny Krzysztof Chodkiewicz, a także Krzysztof Zawisza w Wilnie i Jan Anzelm Wilczek w Mińsku. Krzysztof Zawisza pochodził z rodziny związanej z Sapiehami ${ }^{178}$. Był jednym z wybitniejszych współpracowników podkanclerzego Kazimierza Leona Sapiehy ${ }^{179}$. Wielokrotny poseł, aktywny był szczególnie

168 Ibidem, s. 525-526.

169 M. Sawicki, Stronnictwo, s. 51.

170 Z. Szczerbik, Sejm koronacyjny Władysława IV w 1633 roku, Kluczbork-Praszka 2001, S. 182 .

171 J. Dzięgielewski, Izba poselska, s. 175.

${ }^{172}$ H. Lulewicz, Elita polityczno-spoleczna, s. 171-172.

173 T. Wasilewski, Kiszka Krzysztof, s. 510.

${ }^{174}$ Idem, Kiszka Mikołaj, s. 513; Urzędnicy centralni, nr 411.

175 M. Sawicki, Stronnictwo, s. 71.

${ }^{176}$ Urzędnicy wileńscy, nr 814.

177 M. Sawicki, Stronnictwo, s. 55, 83-84.

${ }^{178}$ Metryka Litewska. Księga wpisów nr 131, oprac. A. Rachuba, Warszawa 2001, s. 6.

${ }^{179}$ M. Sawicki, Stronnictwo, s. 54, 85. 
na sejmiku w Mińsku, gdzie zresztą od 1632 roku przez następne około 20 lat pełnił urząd starosty grodowego. W walce z obozem radziwiłłowskim nie cofał się nawet przed zrywaniem sejmiku, jak to uczynił w 1655 roku $^{180}$.

W 1640 roku sądom przewodniczyli Tomasz Sapieha i Jakub Teodor Kuncewicz. Jakub Teodor Kuncewicz to kolejna wybitna postać należąca do obozu sapieżyńskiego, jednocześnie skoligacona ze swoim protektorem Lwem Sapiehą, poprzez małżeństwo z Heleną Sapieżanką, kuchmistrzanką Wielkiego Księstwa ${ }^{181}$. Po śmierci Sapiehy w 1633 roku cieszył się poparciem Krzysztofa Radziwiłła, który promował Kuncewicza na urząd chorążego lidzkiego w 1639 roku ${ }^{182}$, co sugeruje, że mógł w tym momencie zmienić swoją orientację polityczną. Prawdopodobnie więc w chwili sprawowania funkcji marszałkowskiej zaliczał się do stronników Radziwiłłów birżańskich ${ }^{183}$.

W roku 1641 marszałkami zostali wybrani Jarosław Aleksander Szemiot oraz Adam Owsiany. Pierwszy był stronnikiem sapieżyńskim, blisko związanym ze swoimi protektorami poprzez małżeństwo z Anną Konstancją Sapieżanką, córką wojewody mścisławskiego Andrzeja Sapiehy ${ }^{184}$. Dodatkowo pełnił on w latach 1628-1631 urząd podwojewodziego wileńskiego z ramienia Lwa Sapiehy ${ }^{185}$. Adam Owsiany prawdopodobnie był stronnikiem Janusza Radziwiłła ${ }^{186}$. Jako poseł na sejm w 1647 roku bronił nieobecnego Janusza Radziwiłła w sprawie powywracanych w jego dobrach krzyży. Albrycht Stanisław Radziwiłł zapisał jednak, że zrobił to ,czy to przez pomyłkę, czy zbyt opity winem", nie sugerując wprost, że Owsiany był klientem starosty żmudzkiego ${ }^{187}$.

Spośród pięciu marszałków w 1642 roku - trzech można kojarzyć z fakcją Radziwiłłów birżańskich. Marszałkiem wybranym w dniu inauguracji został wojewoda nowogródzki Aleksander Słuszka. W latach dwudziestych i trzydziestych XVII wieku reprezentował on na sejmikach (głównie mińskim) interesy Radziwiłłów ${ }^{188}$, choć starał się także utrzymywać dobre stosunki z monarchą, nie chcąc narażać się na pomijanie przy rozdawnictwie urzędów i królewszczyzn, co zresztą czynił skutecznie, biorąc pod uwagę karierę, jaką zrobił. W latach czterdziestych usamodzielnił się i jako wojewoda trocki pozwalał sobie nawet na sejmiku, na osobiste mianowanie posłów na sejmy, nic sobie nie czyniąc z protestów szlachty ${ }^{189}$. Z linią birżańską Radziwiłłów związani byli też Samuel Aleksander Komorowski i Michał Konstanty Kolen-

\footnotetext{
${ }^{180}$ A. Rachuba, Wielkie Księstwo, s. 100-101.

${ }^{181}$ T. Wasilewski, Kuncewicz Jakub Teodor, s. 180; Urzędnicy wileńscy, nr 2449.

${ }^{182}$ Ibidem, s. 180.

${ }^{183}$ M. Sawicki, Stronnictwo, s. 159.

${ }^{184}$ M. Nagielski, Sapieha Andrzej, PSB, t. 34, s. 576.

${ }^{185}$ Urzędnicy wileńscy, $\mathrm{nr} 815$.

186 J. Dzięgielewski, Izba poselska, s. 173.

${ }^{187}$ A.S. Radziwiłł, Pamiętnik, t. 3, s. 19-20.

${ }^{188}$ M. Nagielski, Stuszka Aleksander, s. 135.

${ }^{189}$ A.S. Radziwiłł, Pamiętnik, t. 3, s. 23.
} 
da. Ten pierwszy był bez wątpienia jedną z wybitniejszych postaci wśród sług radziwiłłowskich, związany wieloletnią służbą zarówno u Krzysztofa, jak i Janusza Radziwiłłów. Podobnie rzecz wyglądała z Michałem Konstantym Kolendą. Był synem Jana, pisarza ziemskiego wileńskiego i klienta Krzysztofa Radziwiłła ${ }^{190}$. Z woli ojca już w 1624 roku ,został przeznaczony do posług kcia Janusza »na chleb rycerski «"191. W latach 1642-1646 bezpośrednio związany z Aleksandrem Słuszką, z ramienia którego pełnił urząd sędziego grodzkiego trockiego ${ }^{192}$.

Pozostałymi marszałkami byli Antoni Jan Tyszkiewicz i Aleksander Kazimierz Wołłowicz. Jeśli chodzi o rodzinę Wołłowiczów, to była ona skoligacona z Radziwiłłami nieświeskimi poprzez małżeństwo marszałka nadwornego Aleksandra Ludwika Radziwiłła z Teklą Anną Wołłowiczówną ${ }^{193}$. Aleksander Kazimierz zaliczał się do sług Albrychta Stanisława Radziwiłła, który w 1649 roku skutecznie starał się dla niego o chorąstwo wileńskie ${ }^{194}$.

W 1644 roku dyrektorami Trybunału zostali Andrzej Stanisław Sapieha i Krzysztof Rudomina Dusiacki. Marszałek brasławski Krzysztof Rudomina Dusiacki utrzymywał przyjazne kontakty z Januszem Radziwiłłem. Do linii birżańskiej zbliżał rodzinę Rudominów Dusiackich dodatkowo wieloletni konflikt o starostwo uświackie, jaki toczyli oni z Sapiehami ${ }^{195}$.

W 1645 roku marszałkami zostali Piotr Kazimierz Wiażewicz i Stanisław Albrycht Zenowicz. Obaj byli stronnikami Radziwiłłów. Pierwszy był sługą wojewody smoleńskiego Jerzego Karola Hlebowicza, z ramienia którego pełnił urząd podwojewodziego w latach $1643-1653^{196}$. Hlebowicz był związany z Radziwiłłami birżańskimi, o czym najdobitniej świadczy jego mariaż z Katarzyną Radziwiłłówną, córką Krzysztofa Radziwiłła ${ }^{197}$. Musiał mieć także dobre stosunki z kanclerzem Albrychtem Stanisławem Radziwiłłem, skoro ten w 1639 roku po spotkaniu z Hlebowiczem w trakcie obiadu u podkanclerzego Stefana Paca, protegował następnie Wiażewicza do urzędu pisarza wielkiego litewskiego ${ }^{198}$. Sługą kanclerza Radziwiłła był natomiast Stanisław Albrycht Zenowicz, który urząd podkomorzego oszmiańskiego otrzymał w 1649 roku dzięki protekcji kanclerza ${ }^{199}$.

${ }^{190}$ U. Augustyniak, Dwór i klientela, s. 195.

${ }^{191}$ Cyt. za U. Augustyniak, $W$ stużbie, s. 80 przyp. 88; H. Wisner, Kilka uwag, s. 38. Chodzi o Janusza Radziwiłła (1612-1655).

192 Urzędnicy troccy, nr 1088.

${ }^{193}$ A.S. Radziwiłt, Pamiętnik, t. 1, s. 528.

${ }^{194}$ Urzędnicy wileńscy, $\mathrm{nr} 213$.

${ }^{195}$ M. Sawicki, Stronnictwo, s. 40.

${ }^{196}$ Urzędnicy smoleńscy, $\mathrm{nr} 1039$.

${ }^{197}$ W. Czapliński, Hlebowicz Jerzy Karol, PSB, t. 9, 1960-1961, s. 543-544; H. Lulewicz, Elita polityczno-spoleczna, s. 175.

198 A.S. Radziwiłl, Pamiętnik, t. 2, s. 131.

${ }^{199}$ Urzędnicy wileńscy, nr 1687. 
Sesjom Trybunału w 1646 roku przewodniczyli: Kazimierz Tyszkiewicz, Mikołaj Walerian Ciechanowiecki, Samuel Stanisław Drucki Sokoliński i Dymitr Bychowiec. Podkomorzy brzeski Kazimierz Tyszkiewicz mógł być orientacji prosapieżyńskiej i regalistycznej ze względu na małżeństwo z Teofilą Tryźnianką ${ }^{200}$, córką Mikołaja, podskarbiego wielkiego litewskiego w latach $1635-1640^{201}$. Mikołaj Walerian Ciechanowiecki był kolejnym przedstawicielem rodziny związanej z Sapiehami ${ }^{202}$. Bardziej skomplikowana jest orientacja polityczna Druckiego Sokolińskiego. We wcześniejszym etapie swojego życia był on związany z królewiczem Władysławem, administratorem Smoleńszczyzny, oraz wojewodą smoleńskim Aleksandrem Korwinem Gosiewskim, w imieniu których pełnił urząd podwojewodziego w latach 1624$1634^{203}$, a także kapitana smoleńskiego od 1627 roku z nominacji Gosiewskiego $^{204}$. W wojnie smoleńskiej 1632-1634 dowodził obroną oblężonego przez wojska moskiewskie Smoleńska. Utrzymywał przy tym kontakt z hetmanem Krzysztofem Radziwiłłem, dotyczący sytuacji militarneje5, a w następnych latach związał się z nim. Jeszcze w 1640 roku dziękował on Radziwiłłowi za wstawiennictwo u króla w prywatnej spawie majątkowej ${ }^{206}$. Trudno z całą pewnością powiedzieć, czy po 1640 roku nadal zaliczał się on do stronników radziwiłłowskich. Być może zaliczał się już do regalistów, skoro w 1654 roku wszedł w skład dowództwa obrony Smoleńska u boku rok wcześniej mianowanego wojewody Filipa Kazimierza Obuchowicza ${ }^{207}$, zaciekle zwalczanego przez stronników Janusz Radziwiłła.

Niejednorodnie przedstawia się również orientacja polityczna Dymitra Bychowca. Początkowo łączyły go związki z wojewodą trockim Aleksandrem Chodkiewiczem, w imieniu którego pełnił urząd pisarza grodzkiego w latach 1615-1623 $3^{208}$. Następnie był sługą Krzysztofa Radziwiłła i reprezentował interesy księcia na sejmiku trockim w latach dwudziestych i trzydziestych XVII stulecia $^{209}$. Nie ma jednak pewności, czy kontynuował służbę u Radziwiłłów birżańskich po 1640 roku.

Ostatniemu Trybunałowi za panowania Władysława IV przewodniczyli: Janusz Radziwiłł, Jakub Teodor Kuncewicz oraz Stefan Karol Bielikowicz.

${ }^{200}$ K. Niesiecki, Herbarz, s. 180; B. Radziwiłł, Autobiografia, oprac. T. Wasilewski, Warszawa 1979, s. 308.

${ }^{201}$ A. Filipczak-Kocur, Skarbowość Rzeczypospolitej 1587-1648, Warszawa 2006, s. 230.

${ }^{202}$ M. Sawicki, Stronnictwo, s. 52.

${ }^{203}$ Urzędnicy smoleńscy, nr 1036.

${ }^{204}$ M. Nagielski, Sokoliński Samuel Stanisław, PSB, t. 40, 2000, s. 50.

${ }^{205}$ Idem, Szyfrowane depesze Samuela Stanisława Druckiego Sokolińskiego ze Smoleńska z 1633 r., MHA, t. 11, 2000, s. 293.

${ }^{206}$ Ibidem, s. 293.

${ }^{207}$ Ibidem, s. 289.

${ }^{208}$ Urzędnicy troccy, $\mathrm{nr} 806$.

${ }^{209}$ A.B. Zakrzewski, Sejmiki, s. 104; U. Augustyniak, W stużbie, s. 232 przyp. 224. 
Ten ostatni był sługą wojewody wileńskiego Krzysztofa Chodkiewicza, z ramienia którego pełnił urząd podwojewodziego w latach 1647-1652 210 . Niewykluczone, że wcześniej zaliczał się do sług Radziwiłłów birżańskich. Wskazywać na to może małżeństwo z Zofią Wolanówną, wywodzącą się ze związanej z nimi kalwińskiej rodziny ${ }^{211}$.

Z przedstawionej analizy wynika, że najczęściej marszałkami zostawały osoby sympatyzujące lub należące do fakcji Radziwiłłów birżańskich. Szczególnie jest to widoczne w latach 1633, 1634, 1642 i 1648, kiedy większość marszałków stanowili ich stronnicy. Łącznie - z tą fakcją możemy kojarzyć 16 osób, co stanowi 43\% wszystkich osób wybranych dyrektorami za panowania Władysława IV. Jeśli dodamy do tego dwóch marszałków związanych z linią nieświeską Radziwiłłów, odsetek stronników „domu” radziwiłłowskiego byłby jeszcze wyższy. Trzeba jednak pamiętać, że obie linie rodowe współpracowały ze sobą wtedy, gdy chodziło o powagę całej rodziny, a w pozostałych sprawach często się różniły, szczególnie, gdy chodziło o kwestie wyznaniowe ${ }^{212}$.

Stronnicy Sapiehów zostawali marszałkami nieco rzadziej. Do fakcji tej można zaliczyć 12 marszałków, co stanowi około 32\% ogółu. Uwagę zwraca duży udział samych Sapiehów, którzy dyrektorami Trybunału zostawali czterokrotnie, w przeciwieństwie na przykład do linii nieświeskiej Radziwiłłów, której żaden przedstawiciel nie pełnił tej godności w omawianym okresie. Do Trybunałów, gdzie większość marszałków stanowili stronnicy sapieżyńscy, zaliczymy te z 1636 i 1638 roku. Podobnie jak w przypadku fakcji Radziwiłłów birżańskich, także stronnictwo sapieżyńskiej niemal w każdym z 16 Trybunałów potrafiło przeforsować przynajmniej jednego swojego członka na funkcję marszałka.

\section{Spis marszałków.}

Wytłuszczonym drukiem zostały zaznaczone urzędy i godności zajmowane w momencie zasiadania w Trybunale. Skróty godności, urzędów i nazw topograficznych zostały przyjęte za wykazami urzędników litewskich. Zobacz: Urzędnicy wileńscy, s. 51-52, 623.

$$
\begin{aligned}
& \text { kat. - katolik; kalw. - kalwinista; praw. - prawosławny } \\
& \text { n/o - nie odbyła się } \\
& \text { n/p - nie przyjął } \\
& \text { a. }- \text { ante } \\
& \text { c. }- \text { circa } \\
& \text { p. }- \text { post }
\end{aligned}
$$

\footnotetext{
${ }^{210}$ Urzędnicy wileńscy, $\mathrm{nr} 821$.

${ }^{211}$ Ibidem, nr 1629, 1630.

${ }^{212}$ H. Lulewicz, Elita polityczno-społeczna, s. 157-160.
} 


\begin{tabular}{|c|c|c|c|c|c|c|c|}
\hline Rok & Nazwisko i imię & $\begin{array}{l}\text { Data urodzenia } \\
\text { i śmierci }\end{array}$ & $\begin{array}{l}\text { Piastowane } \\
\text { godności } \\
\text { i urzędy }\end{array}$ & 怨 & 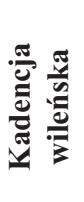 & 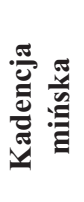 & 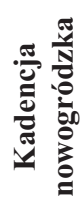 \\
\hline 1 & 2 & 3 & 4 & 5 & 6 & 7 & 8 \\
\hline \multirow{4}{*}{1633} & Pac Jan Kazimierz & c. $1600-1653$ & $\begin{array}{l}\text { dworz. JKM } \\
\text { pis. w. WKsL }\end{array}$ & kat. & $\mathbf{X}$ & $\mathbf{X}$ & \multirow{4}{*}{$\mathrm{n} / \mathrm{o}$} \\
\hline & $\begin{array}{c}\text { Kaweczyński } \\
\text { (Kawieczyński) } \\
\text { Aleksander }\end{array}$ & $?-$ VI 1633 & $\begin{array}{c}\text { dworz. JKM } \\
\text { pkom. wiłkom. }\end{array}$ & $\begin{array}{l}\text { kalw./ } \\
\text { kat. }\end{array}$ & $\mathbf{X}$ & - & \\
\hline & Wilczek Jan Anzelm & $?$ - I 1649 & $\begin{array}{l}\text { dworz. JKM } \\
\text { psęd. oszm. } \\
\text { sta. oszm. } \\
\text { klan. poł. } \\
\text { klan. tr }\end{array}$ & kat. & $\mathbf{X}$ & - & \\
\hline & $\begin{array}{c}\text { Alexandrowicz Jan } \\
\text { Władysław }\end{array}$ & $?-7$ XI 1644 & marsz. grodz. & kat. & $\mathbf{X}$ & - & \\
\hline \multirow{3}{*}{1634} & Sapieha Mikołaj & $\begin{array}{c}\text { c. } 1581-14 \text { III } \\
1644\end{array}$ & $\begin{array}{l}\text { chor. w. WKsL } \\
\text { wda. miń. } \\
\text { wda. brz. } \\
\text { klan. wil. }\end{array}$ & kat. & $\mathbf{X}$ & \multirow{3}{*}{$\mathrm{n} / \mathrm{o}$} & $\mathrm{X}$ \\
\hline & $\begin{array}{l}\text { Sakowicz Adam } \\
\text { Maciej }\end{array}$ & $?-23$ III 1662 & $\begin{array}{l}\text { pkom. oszm. } \\
\text { pwoj. wil. } \\
\text { kon. wil. } \\
\text { sta. oszm. } \\
\text { wda. smol. }\end{array}$ & kat. & $\mathbf{X}$ & & $\mathrm{X}$ \\
\hline & $\begin{array}{l}\text { Giedroyć Marcjan } \\
\text { (Marcin) }\end{array}$ & $?-1649$ & $\begin{array}{l}\text { pstoli. poł. } \\
\text { psęd. wil. } \\
\text { sęd. z. wil. }\end{array}$ & kalw. & $\mathbf{X}$ & & - \\
\hline \multirow{3}{*}{1635} & $\begin{array}{c}\text { Chodkiewicz } \\
\text { Krzysztof }\end{array}$ & $?-3 \times 1652$ & $\begin{array}{c}\text { chor. WKsL } \\
\text { kon. WKsL } \\
\text { klan. tr. } \\
\text { klan. wil. } \\
\text { wda. wil. }\end{array}$ & kat. & $\mathbf{X}$ & $\mathbf{X}$ & \multirow{3}{*}{$\mathrm{n} / \mathrm{o}$} \\
\hline & Białłozor Gabriel & $?-$ a. 25 I 1638 & $\begin{array}{l}\text { sta. nowomłyński } \\
\text { pkom. up. }\end{array}$ & kat. & $\mathbf{X}$ & - & \\
\hline & Tyszkiewicz Michał & $?-$ p. 1647 & $\begin{array}{l}\text { sęd. gr. poł. } \\
\text { pis. z. pol. }\end{array}$ & kat. & - & $\mathbf{X}$ & \\
\hline 1636 & $\begin{array}{c}\text { Dorohostajski } \\
\text { Monwid Władysław }\end{array}$ & $1611-\mathrm{V} 1638$ & $\begin{array}{l}\text { sta. żyżmorski } \\
\text { cz. WKsL }\end{array}$ & kalw. & $\mathbf{X}$ & $\mathrm{n} / \mathrm{o}$ & $\mathrm{X}$ \\
\hline
\end{tabular}




\begin{tabular}{|c|c|c|c|c|c|c|c|}
\hline 1 & 2 & 3 & 4 & 5 & 6 & 7 & 8 \\
\hline \multirow{2}{*}{1636} & Ciechanowiecki Jan & $?$ & $\begin{array}{l}\text { pstoli. mścis } \\
\text { sęd. z. orsz. }\end{array}$ & kat. & $\mathbf{X}$ & \multirow{2}{*}{$\mathrm{n} / \mathrm{o}$} & - \\
\hline & $\begin{array}{l}\text { Szemiot (Szemet, } \\
\text { Szemioth) Gabriel }\end{array}$ & $?$ & pkom. słonim. & kat. & - & & $\mathrm{X}$ \\
\hline 1637 & Kiszka Mikołaj & $\begin{array}{c}\text { c. } 1588-31 \mathrm{III} \\
1644\end{array}$ & $\begin{array}{l}\text { wda. dorp. } \\
\text { sta. wiłkom. } \\
\text { wda. mścis. } \\
\text { sta. wołk. } \\
\text { klan. tr. } \\
\text { sta. wiłkom. } \\
\text { pskar. w. WKsL }\end{array}$ & kat. & $\mathbf{X}$ & $\mathbf{X}$ & $\mathrm{n} / \mathrm{o}$ \\
\hline \multirow{5}{*}{1638} & Kiszka Krzysztof & c. $1590-1646$ & $\begin{array}{c}\text { dworz. JKM } \\
\text { cz. WKsL } \\
\text { wda. mścis. } \\
\text { wda. witeb. }\end{array}$ & kat. & $\mathbf{X}$ & \multirow{5}{*}{$\mathrm{n} / \mathrm{o}$} & $\mathrm{X}$ \\
\hline & $\begin{array}{c}\text { Sapieha Mikołaj } \\
\text { Krzysztof }\end{array}$ & $?-2$ VI 1639 & pis. p. WKsL & kat. & $\mathbf{X}$ & & - \\
\hline & $\begin{array}{c}\text { Alexandrowicz Jan } \\
\text { Władysław }\end{array}$ & $?-7$ XI 1644 & marsz. grodz. & kat. & $\mathbf{X}$ & & - \\
\hline & Mleczko Mikołaj & a. 1587 -c. 1645 & $\begin{array}{l}\text { chor. orsz. } \\
\text { pwoj. wil. } \\
\text { pkom. orsz. }\end{array}$ & $\begin{array}{c}\text { kalw./ } \\
\text { kat. }\end{array}$ & - & & $\mathrm{X}$ \\
\hline & Tyszkiewicz Antoni Jan & $\begin{array}{c}1609-23 \mathrm{VI} \\
1649\end{array}$ & $\begin{array}{c}\text { cz. WKsL } \\
\text { pskar. nadw. WKsL } \\
\text { sta. wiłkom. } \\
\text { marsz. nadw. } \\
\text { WKsL }\end{array}$ & kat. & - & & $\mathrm{X}$ \\
\hline \multirow{3}{*}{1639} & Chodkiewicz Krzysztof & $?-3 \times 1652$ & $\begin{array}{l}\text { chor. WKsL } \\
\text { kon. WKsL } \\
\text { klan. tr. } \\
\text { klan. wil. } \\
\text { wda. wil. }\end{array}$ & kat. & $\mathbf{X}$ & $\mathbf{X}$ & \multirow{3}{*}{$\mathrm{n} / \mathrm{o}$} \\
\hline & $\begin{array}{c}\text { Zawisza Kieżgajło } \\
\text { Krzysztof }\end{array}$ & $?-23$ I 1670 & $\begin{array}{l}\text { łow. WKsL } \\
\text { sta. miń. } \\
\text { pis. w. WKsL } \\
\text { marsz. nadw. } \\
\text { WKsL } \\
\text { marsz. w. WKsL } \\
\text { sta. brasł. } \\
\text { klan. wil. }\end{array}$ & kat. & $\mathbf{X}$ & - & \\
\hline & Wilczek Jan Anzelm & $?-$ I 1649 & $\begin{array}{l}\text { dworz. JKM } \\
\text { psęd. oszm. } \\
\text { sta. oszm. } \\
\text { klan. poł. } \\
\text { klan. tr. }\end{array}$ & kat. & - & $\mathbf{X}$ & \\
\hline
\end{tabular}




\begin{tabular}{|c|c|c|c|c|c|c|c|}
\hline 1 & 2 & 3 & 4 & 5 & 6 & 7 & 8 \\
\hline \multirow[b]{2}{*}{1640} & $\begin{array}{c}\text { Sapieha } \\
\text { (na Holszanach) } \\
\text { Tomasz }\end{array}$ & 1598 - IV 1646 & $\begin{array}{c}\text { Ciw. korszewski } \\
\text { wda. wend. } \\
\text { wda. nowogr. }\end{array}$ & kat. & $\mathbf{X}$ & \multirow[b]{2}{*}{$\mathrm{n} / \mathrm{o}$} & $\mathrm{X}$ \\
\hline & $\begin{array}{c}\text { Kuncewicz Jakub } \\
\text { Teodor }\end{array}$ & $?-28$ VIII 1666 & $\begin{array}{l}\text { pis. z. lidz. } \\
\text { chor. lidz. } \\
\text { pkom. lidz. } \\
\text { klan. miń. } \\
\text { klan. żm. } \\
\text { wda. brz. }\end{array}$ & kat. & $\mathbf{X}$ & & $\mathrm{X}$ \\
\hline \multirow[t]{2}{*}{1641} & $\begin{array}{c}\text { Szemiot Jarosław } \\
\text { Aleksander }\end{array}$ & ? - a. 23 IV 1645 & $\begin{array}{c}\text { dworz. JKM } \\
\text { pwoj. wil. } \\
\text { pkom. wil. }\end{array}$ & kat. & $\mathbf{X}$ & $\mathbf{X}$ & \multirow[t]{2}{*}{$\mathrm{n} / \mathrm{o}$} \\
\hline & Owsiany Adam & ? - a. 3 XI 1649 & $\begin{array}{l}\text { psęd. lidz. } \\
\text { sęd. z. lidz. }\end{array}$ & kat. & $\mathbf{X}$ & - & \\
\hline \multirow{5}{*}{1642} & Słuszka Aleksander & $\begin{array}{c}\text { c. } 1580-\text { VII } \\
1647\end{array}$ & $\begin{array}{l}\text { sta. rzecz. } \\
\text { klan. miń. } \\
\text { klan. żm. } \\
\text { wda. miń. } \\
\text { wda. nowogr. } \\
\text { wda. tr. }\end{array}$ & $\begin{array}{l}\text { kalw./ } \\
\text { kat. }\end{array}$ & $\mathbf{X}$ & \multirow{5}{*}{$\mathrm{n} / \mathrm{o}$} & $\mathrm{X}$ \\
\hline & $\begin{array}{l}\text { Tyszkiewicz } \\
\text { Antoni Jan }\end{array}$ & $\begin{array}{c}1609-23 \mathrm{VI} \\
1649\end{array}$ & $\begin{array}{c}\text { cz. WKsL } \\
\text { pskar. nadw. } \\
\text { WKsL } \\
\text { sta. wiłkom. } \\
\text { marsz. nadw. } \\
\text { WKsL }\end{array}$ & kat. & $\mathbf{X}$ & & - \\
\hline & $\begin{array}{c}\text { Komorowski Samuel } \\
\text { Aleksander }\end{array}$ & $?-20 \times 1659$ & $\begin{array}{l}\text { dworz. JKM } \\
\text { rotm. JKM } \\
\text { pcz. wiłkom. } \\
\text { pstoli. wiłkom. } \\
\text { chor. wiłkom. } \\
\text { ins. WKsL } \\
\text { sta. wiłkom. }\end{array}$ & kat. & $\mathbf{X}$ & & - \\
\hline & $\begin{array}{l}\text { Kolenda Michał } \\
\text { Konstanty }\end{array}$ & $?-1685$ & $\begin{array}{l}\text { sęd. gr. tr. } \\
\text { chor. dorp. } \\
\text { psęd. wil. } \\
\text { sęd. z. wil. }\end{array}$ & kat. & $\mathbf{X}$ & & - \\
\hline & $\begin{array}{c}\text { Wołłowicz Aleksander } \\
\text { Kazimierz }\end{array}$ & ? - a. $12 \times 1660$ & $\begin{array}{l}\text { pis. z. słonim. } \\
\text { chor. wil. }\end{array}$ & kat. & - & & $\mathrm{X}$ \\
\hline 1643 & $\begin{array}{l}\text { Chodkiewicz } \\
\text { Krzysztof }\end{array}$ & $?-3 \times 1652$ & $\begin{array}{l}\text { chor. WKsL } \\
\text { kon. WKsL } \\
\text { klan. tr. } \\
\text { klan. wil. } \\
\text { wda. wil. }\end{array}$ & kat. & $\mathbf{X}$ & $\mathbf{X}$ & $\mathrm{n} / \mathrm{o}$ \\
\hline
\end{tabular}




\begin{tabular}{|c|c|c|c|c|c|c|c|}
\hline 1 & 2 & 3 & 4 & 5 & 6 & 7 & 8 \\
\hline \multirow[t]{2}{*}{1644} & $\begin{array}{l}\text { Sapieha Andrzej } \\
\text { Stanisław }\end{array}$ & $\begin{array}{c}1592-25 \text { III } \\
1646\end{array}$ & $\begin{array}{c}\text { dworz. JKM } \\
\text { sta. ryski } \\
\text { wójt grodz. } \\
\text { klan. tr. } \\
\text { klan. wil. }\end{array}$ & kat. & $\mathbf{X}$ & \multirow[t]{2}{*}{$\mathrm{n} / \mathrm{o}$} & $\mathrm{X}$ \\
\hline & $\begin{array}{c}\text { Rudomina Dusiacki } \\
\text { Krzysztof }\end{array}$ & $?-$ a. 7 V 1655 & $\begin{array}{c}\text { dworz. JKM } \\
\text { marsz. brasł. } \\
\text { klan. poł. } \\
\text { wda. miń. }\end{array}$ & kat. & - & & $\mathrm{X}$ \\
\hline \multirow[t]{2}{*}{1645} & $\begin{array}{l}\text { Wiażewicz Piotr } \\
\text { Kazimierz }\end{array}$ & $?-2$ IV 1657 & $\begin{array}{l}\text { stol. mścis. } \\
\text { pwoj. smol. } \\
\text { pkom. mścis. } \\
\text { wójt orsz. } \\
\text { kapitan smol. } \\
\text { sur. gr. smol. } \\
\text { wójt mścis. } \\
\text { wójt smol. } \\
\text { wda. nowogr }\end{array}$ & kat. & $\mathbf{X}$ & $\mathbf{X}$ & \multirow[t]{2}{*}{$\mathrm{n} / \mathrm{o}$} \\
\hline & $\begin{array}{c}\text { Zenowicz Stanislaw } \\
\text { Albrycht }\end{array}$ & ? - XII 1665 & $\begin{array}{l}\text { dworz. JKM } \\
\text { pis. z. oszm. } \\
\text { pkom. oszm. }\end{array}$ & kat. & $\mathbf{X}$ & $\mathbf{X}$ & \\
\hline \multirow{4}{*}{1646} & $\begin{array}{l}\text { Tyszkiewicz } \\
\text { Kazimierz }\end{array}$ & $1613 ?-1649$ & $\begin{array}{c}\text { pkom. brz. } \\
\text { klan. brz. }-\mathrm{n} / \mathrm{p} ?\end{array}$ & kat. & $\mathbf{X}$ & \multirow{4}{*}{$\mathrm{n} / \mathrm{o}$} & $\mathrm{X}$ \\
\hline & $\begin{array}{l}\text { Ciechanowiecki } \\
\text { Mikołaj Walerian }\end{array}$ & $?-1672$ & $\begin{array}{c}\text { miecz. mścis. } \\
\text { sta. mścis. } \\
\text { wda. mścis. }\end{array}$ & kat. & $\mathbf{X}$ & & - \\
\hline & $\begin{array}{l}\text { Drucki Sokoliński } \\
\text { Samuel Stanislaw }\end{array}$ & $?-\mathrm{X} 1654$ & $\begin{array}{l}\text { dworz. JKM } \\
\text { pwoj. smol. } \\
\text { kapitan smol. } \\
\text { pkom. smol. }\end{array}$ & kat. & $\mathbf{X}$ & & - \\
\hline & Bychowiec Dymitr & $?-1650$ & $\begin{array}{l}\text { pis. gr. tr. } \\
\text { psęd. tr. } \\
\text { sęd. z. tr. }\end{array}$ & praw. & - & & $\mathrm{X}$ \\
\hline \multirow{2}{*}{1647} & $\begin{array}{l}\text { Chodkiewicz } \\
\text { Krzysztof }\end{array}$ & $?-3 \times 1652$ & $\begin{array}{l}\text { chor. WKsL } \\
\text { kon. WKsL } \\
\text { klan. tr. } \\
\text { klan. wil. } \\
\text { wda. wil. }\end{array}$ & kat. & $\mathbf{X}$ & $\mathbf{X}$ & \multirow{2}{*}{$\mathrm{n} / \mathrm{o}$} \\
\hline & $\begin{array}{l}\text { Tyszkiewicz } \\
\text { Antoni Jan }\end{array}$ & $\begin{array}{c}1609-23 \mathrm{VI} \\
1649\end{array}$ & $\begin{array}{c}\text { cz. WKsL } \\
\text { pskar. nadw. WKsL } \\
\text { sta. wiłkom. } \\
\text { marsz. nadw. } \\
\text { WKsL }\end{array}$ & kat. & $\mathbf{X}$ & - & \\
\hline
\end{tabular}




\begin{tabular}{|c|c|c|c|c|c|c|c|}
\hline 1 & 2 & 3 & 4 & 5 & 6 & 7 & 8 \\
\hline \multirow{3}{*}{1648} & Radziwiłł Janusz & $\begin{array}{c}2 \text { XII } 1612- \\
30 / 31 \text { XII } 1655\end{array}$ & $\begin{array}{l}\text { pkom. WKsL } \\
\text { sta. mścis. } \\
\text { klan. tr. - n/p } \\
\text { het. p. WKsL } \\
\text { sta. } \mathbf{z} m . \\
\text { wda. wil. } \\
\text { het. w. WKsL }\end{array}$ & kalw. & $\mathbf{X}$ & \multirow{3}{*}{$\mathrm{n} / \mathrm{o}$} & \multirow{3}{*}{$\mathrm{n} / \mathrm{o}$} \\
\hline & $\begin{array}{c}\text { Kuncewicz Jakub } \\
\text { Teodor }\end{array}$ & ? - 28 VIII 1666 & $\begin{array}{c}\text { pis. z. lidz. } \\
\text { chor. lidz. } \\
\text { pkom. lidz. } \\
\text { klan. miń. } \\
\text { klan. żm. } \\
\text { wda. brz. }\end{array}$ & kat. & $\mathbf{X}$ & & \\
\hline & $\begin{array}{c}\text { Bielikowicz Stefan } \\
\text { Karol }\end{array}$ & ? - p. 20 XI 1655 & $\begin{array}{l}\text { dworz. JKM } \\
\text { pcz. oszm. } \\
\text { pwoj. wil. }\end{array}$ & kat. & $\mathbf{X}$ & & \\
\hline
\end{tabular}

VII. Marszałkami Trybunału w badanej epoce zostawała szlachta, najczęściej pełniąca w swoich powiatach urzędy ziemskie lub grodzkie. Dyrektorami Trybunału nierzadko byli też senatorowie. Najliczniejszą grupą urzędników byli podkomorzowie, którzy marszałkami zostawali dziewięć razy. Główną przyczyną atrakcyjności funkcji marszałka była najpewniej bezpośrednia możliwość wpływania na wyroki zapadające przed Trybunałem, które mogły dotyczyć interesów polityczno-majątkowych głównych postaci litewskiej polityki. Innym czynnikiem mogła być też chęć pokazania się królowi i szlachcie, a więc - względy prestiżowe. Większość marszałków (70\%) zaliczyła też awanse w hierarchii urzędniczej, co skłania do tezy, że pełnienie tej funkcji mogło stanowić jeden z elementów „wspomagających” możliwość promocji jednostki na wyższy urząd.

Pod względem wyznaniowym zdecydowana większość osób będących marszałkami wyznawała katolicyzm (89\%). Innowiercami zostało tylko czterech marszałków - trzech kalwinistów i jeden prawosławny. Byli oni marszałkami w latach 1634, 1636, 1646 i 1648.

Zestawiając marszałków pod względem przynależności do stronnictw politycznych, z fakcją Radziwiłłów birżańskich można kojarzyć 16 osób, co stanowi $43 \%$ wszystkich dyrektorów za panowania Władysława IV. Stronnicy Sapiehów zostawali marszałkami nieco rzadziej: 12 osób, stanowiących około $32 \%$ ogółu. Dwóch marszałków było klientami Radziwiłłów nieświeskich, pozostali zaś - prawdopodobnie - byli regalistami. Zarówno fakcja Radziwiłłów birżańskich jak i stronnictwo sapieżyńskie niemal na każdym z 16 Trybunałów potrafiło przeforsować przynajmniej jednego swojego członka na funkcję 
marszałka, co świadczy o względnej równowadze stronnictw oraz obrazuje istotną rolę tej funkcji w życiu politycznym Wielkiego Księstwa Litewskiego.

\author{
TEMPORAL MARSHALS OF THE HIGH TRIBUNAL OF THE GRAND \\ DUCHY OF LITHUANIA DURING THE REIGN OF WŁADYSŁAW IV VASA, \\ $1633-1648$
}

\title{
Summary
}

The proceedings of the High Tribunal of the Grand Duchy of Lithuania were presided over by a Marshal, also known as director of the Tribunal in the $17^{\text {th }}$ century. He was elected from among all the deputies on the inauguration day of a new tribunal. The position was commonly filled by Lithuanian officials of various ranks and it was not uncommon for senators to serve as Marshals. For various reasons, a Marshal was not always able to take part in all the activities of the Tribunal - on such occasions assistant Marshals were elected. In 1633, 1634, 1635, 1636, 1638, 1639, 1642, 1646 and 1648, the High Tribunal was presided over by at least three directors. The most High Tribunals Marshals presided over (there were as many as five) were in 1638 and 1642. In total, in 16 Lithuanian High Tribunals, which convened during the reign of Władysław IV, the position was filled by 37 persons, 45 times in all.

Because of the political and property interests of Lithuanian political elites and opportunities to influence judgments, the position of the High Tribunal director was attractive.

Out of 37 High Tribunal Marshals 17, or 46 per cent, were senators or were to become senators later. In terms of denominational affiliation, the High Tribunal was presided over by 33 Catholics, 3 Calvinists and a single Orthodox.

High Tribunal Marshals were - in principle - elected deputies at the dietines of Lithuanian 'upper voivodeships', chiefly though from the Vilnius Voivodeship. Out of 45 High Tribunal Marshals, 20 came from these dietines, which accounts for 44 per cent of all Tribunal directors in 1633-1648.

\section{LES MARÉCHAUX LAÏQUES DU TRIBUNAL GÉNÉRAL DU GRAND - DUCHÉ DE LITUANIE SOUS LE RĖGNE DE LADISLAS IV WAZA, $1633-1648$}

\section{Résumé}

Les séances du Tribunal Général du Grand-Duché de Lituanie sont présidées par le maréchal, appelé également au XVII ${ }^{\mathrm{e}}$ siècle directeur du Tribunal. Ce dernier est 
désigné parmi tous les députés le jour de l'inauguration du tribunal. Cette fonction est remplie le plus souvent par les fonctionnaires lituaniens de différents échelons, étant souvent les sénateurs. Pour de différentes raisons, le maréchal ne peut pas participer en parmanence à toutes les activités du Tribunal - sont donc nommés, le cas échéant, ses adjoints. Dans les années 1633, 1634, 1635, 1636, 1639, 1642, 1646 et 1648, il y a eu au moins trois directeurs qui ont présidé les séances du Tribunal Général. En 1638 et 1642, ils sont au plus grand nombre, à savoir cinq. Au total, au service de 16 Tribunaux lituaniens qui se sont réunis durant le règne de Ladislas IV, cette fonction est exercée par 37 personnes, 45 fois au total. Eu égard aux intérêts politiques et patrimoniaux de l'élite politique de la Lituanie ainsi qu'aux possibilités d'influer sur les jugements rendus, la fonction de directeur du Tribunal Général devient attractive. 17 personnes parmi 37 maréchaux de tribunal étaient sénateurs ou devaient le devenir dans l'avenir, ce qui représente $46 \%$ du groupe total. En ce qui concerne la confession, les présidents du Tribunal étaient : catholiques, au nombre de 33, calvinistes -3 et seulement un orthodoxe. Les Maréchaux du Tribunal étaient en principe désignés députés de la diétine « de la haute voïvodie » lituanienne, notamment de la voïvodie de Vilnius. 20 sur 45 maréchaux du Tribunal Général sont originaires de ces diétines, ce qui représente $44 \%$ de l'ensemble des directeurs du Tribunal en exercice pendant les années 1633-1648. 